UC-NRLF

||||||||||||||||||||||||||||||||||||

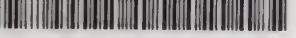

+B 36 25b 



\title{
hara ftatbematica;
}

OR,

\author{
A COLLECTION
}

or

\section{TREATISES ON THE MATHEMATICS}

A N D

SUBJECTS CONNECTED WITH THEM,

from ancient inedited ftetanuscripts.

EDITED BY

JAMES ORCHARD HALLIWELL, EsQ., F.R.S., F.s.A. \&c. \&c.

OF JESUS COLLEGE, CAMBRIDGE.

"I see not how the history of any science is to be conducted through the middle-age period, but by the assistance of the works of science of the middle-age writers, though the contents of them, as works of science, may have now become of little value."

Rev. J. Hunter's Monastic Libraries, Pref. p. xi.

\section{LONDON:}

JOHN WILLIAM PARKER, WEST STRAND;

J. \& J. J. DEIGHTON, \& T. STEVENSON,

CAMBRIDGE.

1839. 
CAMBRIDGE :

PRINTED BY METCALFe AND PALMER, trinity STREeT. 


\section{Q 153 \\ $\mathrm{H} 2$}

THOMAS STEPHENS DAVIES, Esq. F.R.S. L.\& E.

Royal Military Academy, Woolwich.

\section{MY DEAR SiR,}

I claim the privilege of inscribing this book to you, because, as my first public effort in literature, it iswhether good for anything or not-the most sincere present I can make to my best and most valued friend.

It may seem rather irrelevant to the purposes of a dedication, if I allude to the early mathematics of your own country. It may not be generally known, that many of the men of science who adorned the walls of the University of Oxford in the middle ages, were Welehmen: and I mention this, because the title of a work lately announced has excited a question relative to the existence of materials requisite for writing a history of the early progress of science in that principality. I am not surprised at the question when I take into consideration, that a man-or rather a boy-who arrogates to himself the title of the Welch mathematical representative of England, once said in the dining-hall of my own College, when a dispute about Demoivre's theorem had arisen, that " he thought Demoivre a very elever man, having 
written some praiseworthy articles on the expansion of series in the Philosophical Magazine!" How would the manes of Gwdion, Gwyn, and Idris be horrified, were they to hear of such a desecration of the sacred rights of history !

You, I am sure, will be pleased to see the labours of some of your predecessors brought to light. They will serve to give additional lustre to the exertions of the best geometrician in England; and the transcriber will feel himself invigorated by the hope of being able to fill up a chasm in history, being convinced that he has left the meritorious labours of later writers-Anderson, Fermat, Simson, and Playfair-in better and more able hands.

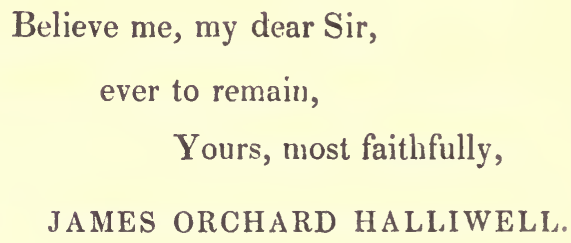

Jesus College, Cambridge.

March 1st, 1839. 


\section{P R E F A C E.}

I HAVE thought it unnecessary to enter very fully into the history of the several treatises in this volume, because it will be done at large in my history of early English Mathematics, now in the course of rapid preparation for the press. The following notes on some of them may not prove unacceptable.

I. Johannes de Sacro-Bosco de Arithmetica. Often occurs in MSS. without his name; MSS. Harl. 3647. 3843. 4350. Bib. Reg. 12 C. xvii. Arund. 343. Cott. Cleop. B. vi. f. 234. Publ. Cantab. Ii. I. 15. (1692). An English translation-Ashm. 396. The present text is taken from a MS. in my own library, purchased at the sale of the Library of the Abbate Canonici of Venice.

III. A Treatise on the Numeration of Algorism.-This is taken from a single leaf of vellum, found loose in an old MS. on astronomy in my possession : from Dr. Clarke's library.

IV. Bourne's Treatise on Optical Glasses.-The other work he mentions in his dedication, as having been inscribed to Lord Burghley, is in the British Museum. MS. Sloan. 3651.

V. Johannes Robyns de Cometis.-From a MS. in my own library, Other copies, Bib. Reg. 12 B. xv. and Trin. Coll. Cantab. inter MSS. Gal. O. I. 11.

VIII. A Merchant's Account Table.-This table is exceedingly curious, conducted partly similar to an abacus, the cyphers at the bottom being used to guide the manual calculator. 
IX. Carmen de Algorismo. - A MS. of the Massa Compoti in the British Museum (Harl. 3902), by Alexander de Villa Dei, possesses an introduction to the work by some other author: it is there stated that the same author composed Doctrinale et Algorismum Metricum. M. Chasles informs me that a MS. of this tract in the French King's Library (7420. A.) has the following colophon at the end: Explicit Algorismus editus a Magistro Alexandro de Villa Dei. This is, I think, quite sufficient to prove him to be the author.

MSS. of it are very numerous : I will mention a few for guidance. MSS. Bib. Reg. 8 C. iv. 12 E. i. 12 F. xix. Cot. Vitell. A. i. (first chapter). Trin. Coll. Cant. O. v. 4. ii. 45. i. 31. S. John. F. 18. Publ. Mm. iii. 11. (2310). Ii. i. 13. (1690.) i. 15. (1692). Bodl. 57. Fairf. 27. Digb. 15. 22. 81. 97. 98. 104. 190. Bodl. 4to. D. 21. Jur. Fragments MSS. Sloan. 513. 1620. 2397.-Many copies of it occur in the Catalogue of the Library of the Dover Monastery (MS. Bodl. 920.) made in 1389._ Vid. Monast. iv. p. 532 .

MS. Digb. 104, has Ambrosinus for Algorismus in the first line. MS. Sloan. 513, has the following colophon-

"Explicit traetatus algorismi tum satis breve et bono commento secundum Saxton.

Qui scripsit carmen sit benedictus. Amen!

Nomen scriptoris Galfridus plenus Amoris."

Whose name is here latinized I know not, but I am not inclined to give much credit to it.

XII. The Preface to an Almanac for 1430.-It was pointed out to me by a friend, that some portions of this are evidently plagiarized from Chaucer's preface to his tract on the Astrolabe. 


\section{O N T E N TS.}

PAGE

I. Johannis de Sacro-Bosco Tractatus de Arte Numerandi.................................. 1

II. A method used in England in the fifteenth century for taking the altitude of a steeple or inaccessible object...........................

111. A Treatise on the Numeration of Algorism........

IV. A Treatise on the properties and qualities of glasses for optical purposes, according to the making, polishing, and grinding of them.-By WILLIAM Bourne........................................

V. Johannis Robyns de Cometis Commentaria.........

VI. Two Tables: one shewing the time of high water at London bridge, and the other the duration of moon-light. From a MS. of the 13th century.

VII. A Treatise on the mensuration of heights and distances.

VIII. An Account Table for the use of merchants.... .. 72

IX. Alexandri de Villa Dei Carmen de Algorismo. ... 73

X. Prefatio Danielis de Merlai ad librum de naturis superiorum et inferiorum................... 
XI. Proposals for some inventions in the Mechanical Arts... .................................. 86

XII. The Preface to a calendar or almanac for the

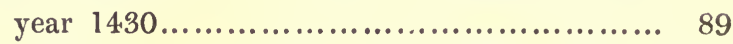

XIII. Johannis Norfolk in artem progressionis summula. 94 XIV. Appendix................................. 107 


\title{
JOANNIS DE SACRO-BOSCO
}

\author{
TRACTATUS
}

\section{DE ARTE NUMERANDI.}

OMNIA quæ a primæva rerum origine processerunt ratione numerorum formata sunt, ${ }^{1}$ et quemadmodum sunt, sic cognosci habent: unde in universa rerum cognitione, ars numerandi est operativa. Hanc igitur scientiam numerandi compendiosam edidit philosophus nomine Algus, 2 unde algorismus nuncupatur, vel ars numerandi,

1 "Omnia quæcunque a primæva rerum natura constructa sunt, numerorum videntur ratione formata."-Boetii Arith. lib. i. cap. 2, Edit. Par. 1521, fol. 8. Vid. Hen. Welpii Arith. Practica, 4to. Colon. 1543. Enchiridion Algorismi per Joannem Huswirt, 4.to. Colon. 1501. Licht de Algorismo, 4to. Leip. 1500.

2 "Rex quondam Castelliæ." Johannis Norfolk progressionis summula, MS. Harl. Mus. Brit. 3742. "Cum hæc scientia de numeris quæ algorismus ab inventore vel ab Algo, quæ est inductio et rismus, quæ est numerus quasi inductio in numeros appellatur."--Tractatus de Algorismo, MS. Arundel. M.B. 332, fol. 68. Vid. Pref. a "CEuvre tresubtille et profitable de Arithmetique et Geom." 4to. Par. 1515, Sig. B. 2. 
vel introductio in numerum. Numerus quidem dupliciter notificatur, formaliter et materialiter : formaliter ut numerus est multitudo ex unitatibus aggregata: materialiter ut numerus est unitates collectæ. Unitas autem est qua unaquæque res una dicitur. Numerorum alius digitus $;^{3}$ alius articulus; alius numerus compositus sive mixtus. Digitus quidem dicitur omnis numerus minor denario; articulus vero est omnis numerus qui potest dividi in decem partes æquales, ita quod nihil residuum sit; compositus vero sive mixtus est qui constat ex digito et articulo. Et sciendum est quod omnis numerus inter duos articulos proximos est numerus compositus. Hujus autem artis novem ${ }^{4}$ sunt species; scilicet, numeratio, additio, subtractio, mediatio, duplatio, multiplicatio, divisio, progressio, et radicum extractio ; et hæc dupliciter in cubicis èt quadratis; inter

3 “Digitus est omnis numerus minor decem. Articulus est omnis numerus qui digitum decuplat, aut digiti decuplum, aut decupli decuplum, et sic in infinitum. Separantur autem digiti et articuli in limites. Limes est collectio numerorum, qui aut digiti sunt, aut digitorum æquæmultiplices, quilibet sui relativi. Limes itaque primus digitorum, secundus primorum articulorum. Tertius est secundorum articulorum. Et sic in infinitum. Numerus compositus est qui constat ex numeris diversorum limitum. Item numerus compositus est qui pluribus figuris significativis representatur."-Algorismus demonstratus Regiomontani, edit. 1534, Sig. A. iv.

${ }^{4}$ Prodocimus de Beldemando de Padua facit idem divisionem, sed Lucas Paciolus de Burgo Sancti Sepulchri omittit duplationem et mediationem. Vid. Wallisii Opera, tom. iii. Art. Alg. 
quas primo de numeratione et postea de aliis per ordinem dicetur.

\section{I.-Numeratio.}

Est autem numeratio cujuslibet numeri per figuras competentes artificialis representatio. Figura vero differentia locus et limes idem supponunt, sed diversis rationibus imponuntur. Figura dicitur quantum ad lineæ pertractionem. Differentia vero quantum per illam ostenditur qualiter figura precedens differat a subsequenti. Locus vero dicitur ratione spatii in quo scribitur. Limes ${ }^{5}$ quia est via ordinata ad cujuslibet muneri representationem. Juxta igitur novem limites inveniantur novem figuræ, novem digitos representantes; quæ tales sunt, 9.8.7.6.5.4.3.2.1. Decima figura dicitur theta, ${ }^{6}$ vel circulus, vel cifra, ${ }^{7}$ vel figura nihili quia nihil significat, sed locum tenens dat aliis significare: nam sine cifra vel cifris purus non potest scribi articulus. Cum igitur

5 "Numerorum diversi sunt limites. Primus enim limes restat ab unitate usque ad denarium; a denario in centenarium: a centenario in millenarium: et sic per decuplum. Secundus limes a binario usque ad vigenarium: a vigenario usque ad ducenta; a ducentis usque ad duo millia. Similiter et cæteri per cæteros digitos sumuntur. Sunt autem tot limites quot digiti."-MS. de Algorismo, Bib. Trin. Col. Cant. Gal. Collect. O 2. 45, fol. 37.

${ }_{6}$ In multis MSS. teca et theca.

7 Vid. Noviomagus de Numeris, 12mo. Par. 1539, p. 40. Vossius de Scien. Math. et Wallisii Algebra, Angl. edit. p. 9. 
per has novem figuras significativas adjunctas quandoque cifræ quandoque cifris contingat quemlibet numerum representare, non fuit necesse plures invenire figuras significativas. Notandum igitur quod quilibet digitus una sola figura sibi appropriata habet scribi. Omnis vero articulus per cifram primo positam et per figuram digiti a quo denominatur, ille articulus habet representari vel denominari. Quilibet articulus ab aliquo digito denominatur, ut denarius ab unitate, vigenarius a binario, et sic de aliis. Omnis numerus in eo quod digitus habet poni in prima differentia: omnis articulus in secunda. Omnis vero numerus a decem usque ad centum, ut centenarius excludatur, scribatur duabus figuris; si sit articulus, per cifram primo loco positam et figuram scriptam versus sinistram quæ significat digitum a quo denominatur ille articulus; si sit numerus compositus, scribatur digitus qui est pars illius numeri compositi et sinistretur articulus. Item omnis numerus a centum usque ad mille, ut millenarius excludatur, per tres figuras habet scribi. Item omnis numerus a mille usque ad decem millia, per quatuor figuras habet scribi, et sic deinceps. Notandum quod quælibet figura primo loco posita significat suum digitum: secundo decies suum digitum: tertio centies suum digitum; quarto loco millesies; quinto loco decies millesies; sexto loco centies millesies; septimo loco millesies millesies, 
et sic usque ad infinitum multiplicando per hæc tria, decem, centum, mille: quæ tamen omnes continentur in hac maxima; quælibet figura in sequenti loco posita decies tantum significat quantum in præcedenti. Item sciendum est quod supra quamlibet figuram loco millenarii positam componenter possunt poni quidam punctus ad denotandum quod tot millenarios debet ultima figura representare, quot fuerunt puncta pertransita. Sinistrorsum autem scribimus in hac arte more Arabum hujus scientiæ inventorum, vel hac ratione ut in legendo, consuetum ordinem observantes numerum majorem proponamus.

\section{II.-Additio.}

Additio $^{8}$ est numeri vel numerorum aggregatio, ut videatur summa excrescens. In additione duo ordines figurarum et duo numeri adminus sunt necessarii, numerus cui debet fieri additio, et numerus qui recipit additionem alterius et debet superscribi. Numerus vero addendus est ille qui debet addi ad alium, debet subscribi, et competentius est ut minor numerus subscribatur et majori addatur. $\mathrm{Si}$ igitur velis numerum

8 " Additio est numeri ad numerum aggregatio, ut videatur summa excrescens : vel aliter : additio est duorum numerorum tertii inventio qui ambos contineat. In additione duo sunt ordines et duo numeri sunt necessarii ; scilicet, numerus addendus et numerus cui debet fieri additio."-MS. de Arithmetica, Mus. Brit. Arundel. 332, fol. 68, b. 
addere numero, scribe numerum cui debet fieri additio in superiori ordine per suas differentias; numerum vero addendum in inferiori ordine per suas differentias, ita quod prima inferioris ordinis sit sub prima superioris ordinis, secunda sub secunda, et sic de aliis. Hoc facto, addatur prima inferioris ordinis primæ superioris ordinis; ex tali ergo additione aut excrescat digitus, aut articulus, aut numerus compositus. Si digitus, loco superioris deletæ scribatur digitus excrescens. Si articulus, loco superioris deletæ scribatur cifra et transferatur digitus a quo denominatur ille articulus versus sinistram partem, et addatur proximæ figuræ sequenti, si sit figura sequens; si nulla, sit figura ponatur in loco vacuo. $\mathrm{Si}$ autem contingat quod figura sequens cui debet fieri additio articuli sit cifra, loco illius deletæ scribatur digitus articuli. Si vero contingat quod sit figura nonenarii, et ei debeat fieri additio unitatis; loco illius nonenarii deletæ scribatur cifra, et sinistretur articulus ut prius. Si autem excrescat numerus compositus, loco superioris deletæ scribatur digitus, pars illius numeri compositi, et sinistretur articulus ut prius. Hoc facto, addatur secunda secundæ sibi suprapositæ, et fiat ut prius.

\section{III.-Subtractio.}

Subtractio est, propositis duobus numeris, majoris ad minorem excessus inventio: vel sic, 
subtractio est numeri a numero ablatio, ut videatur summa excrescens. Minor autem de majori subtrahi potest, vel par de pari; major vero de minori nequaquam. Ille quidem numerus major est qui plures habet figuras, dummodo ultima sit significativa: si vero tot sint unitates in uno quot in alio reliquo, videndum est per ultimas vel penultimas, et sic deinceps. In subtractione vero duo sunt numeri necessarii; scilicet, numerus subtrahendus, et numerus a quo debet fieri subtractio. Numerus subtrahendus debet sibi scribi per suas differentias, ita quod prima sub prima, secunda sub secunda, et sic de aliis. Subtrahe ergo primam figuram inferioris ordinis a figura sibi supraposita, et illa aut erit par, aut major, aut minor. Si par, ea deleta loco ejus ponatur cifra, et hoc propter figuras sequentes ne minus significent. Si major supponatur, tunc deleantur tot unitates quot contineat inferior figura et residuum loco ejus ponatur. Si minor quam, major numerus de minori subtrahi non potest, mutuetur unitas a figura proxima sequente quæ valet decem respectu precedentis figuræ; ab illo ergo denario et a figura a qua debuit fieri subtractio simul junctis subtrahatur figura inferior et residuum ponatur in loco figuræ deletæ. Si vero figura a qua mutuanda est unitas sit unitas, ea deleta loco ejus scribatur cifra ne figuræ sequentes minus significent deinde operare ut prius. Si vero figura a qua mutuanda est unitas sit cifra, accedet ad proximam figuram significativam et 
ibi mutuat unitate et in redeundo in loco cujuslibet cifræ pertransitæ ponatur figura nonenarii ; cum igitur perventum fuerit ad illam figuram de qua intenditur, remanebit tibi denarius ab illo ergo denario, et a figura non potest fieri subtractio simul junctis subtrahatur figura sibi supposita ut prius. Ratio autem quare loco cujuslibet cifræ pertransitæ relinquitur nonenarii figura hæc est. Si autem tertio loco mutuetur unitas illa respectu illius a qua debuit fieri subtractio, valuit centum ; sed loco cifræ pertransitæ, relinquitur nonenarius qui valet nonaginta, unde remanet tantum denarius, et eadem erit ratio si a quarto loco vel a quinto vel deinceps mutuetur unitas. Hoc facto, subtrahe secundam inferioris ordinis a sua superiori, et negociandum est ut prius. Sciendum est quod tam in additione quam in subtractione possumus incipere operari a sinistra parte tendendo versus dextram; sed, ut dicebatur, fuit commodius. Si autem probare volueris utrum bene feceris, nec ne figuras quas prius subtraxisti adde superioribus, et concurrent exdem figuræ si recte feceris, quas prius habuisti. Similiter in additione, quum omnes figuras addideris, subtrahas quas prius addidisti et redibunt eædem figuræ quæ prius habuisti, si feceris recte: est enim subtractio additionis probatio, et converso. ${ }^{9}$

9 "Una species probat aliam; si itaque volueris explorare veritatem calculi in additione, subtrahe partes conjungendas $a b$ aggregato: sique nihil remanet, vera est operatio. E contra vero, in subtractione exploraturus calculum, adde relictum ad 


\section{IV.-Mediatio.}

Mediatio est numeri propositi medietatis inventio, ut videatur quæ et quanta sit illa medietas. In mediatione autem tantum est unus ordo figurarum et unus numerus necessarius, scilicet, numerus mediandus. Si ergo velis numerum aliquem mediare, scribatur ille numerus per suas differentias et incipe a dextris, scilicet, a prima figura versus dextram tendendo ad sinistram. Prima igitur figura aut erit significativa aut non : si non sit significativa, cifra præmittatur et fiat alterius: si vero fuerit significativa, ergo representabit unitatem aut alium digitum : si unitatem loco ejus deletæ ponatur cifra propter figuras sequentes ne minus significent, et scribatur illa unitas exterius in tabula, vel resolvatur illa unitas in sexaginta minuta, et medietas illorum sexaginta abjiciatur et reliqua medietas reservetur exterius in tabula, vel scribatur figura dimidii: sciendum tum quod nullum ordinis locum obtineat aliquod, tamen significat quod medietas duplata in suum locum recipiatur in duplatione. Si autem prima figura significet alium digitum ab unitate, ille numerus aut erit par aut impar. Si par, loco ejus deletæ scribatur medietas illius numeri paris. Si impar, sume

numerum subtrahendum, cumque redit is, a quo subtractio facta est, justa est operatio."-Winshemii Compendium Logistica Astronomica, 12mo. 1563, Sig. B. 3. 
numerum proximum parem sub illo contentum, et medietatem ejus pone in loco illius imparis deleti; de unitate autem quæ remanet medianda, fac ut prius. Hoc facto, medianda est secunda figura et negocianda est ut prius, si cifra prætermittatur intacta. Si autem figura sit significativa, aut par aut impar erit: si par, loco ejųs deletæ scribatur ejus medietas; si impar, aut erit unitas aut alius digitus numerum imparem representans. Si unitas, loco ejus deletæ scribatur cifra. Illa autem unitas cum valet decem respectu figuræ prioris de illis decem sumatur medietas : quinarius et addatur figuræ præcedenti. Si vero fuerit alius digitus numerum imparem representans, sume proximum parem sub illo contentum, et medietas ejus loco illius imparis deletæ ponatur: unitas autem quæ remanet medianda valet decem respectu figuræ præcedentis: dividatur ergo ille denarius in duos quinarios, et unus illorum abjiciatur, et reliquus addatur figuræ præcedenti ut prius. Si autem cifra fuerit cui debet addi quinarius, deleatur cifra, et loco ejus scribatur quinarius, et sic operandum est donec totus numerus mediatur qui scriptus fuerit.

\section{V.-Duplatio.}

Duplatio est numeri propositi ad seipsum aggregatio, ut videatur summa excrescens. In duplatione tantum unus ordo figurarum est necessarius. In tribus speciebus precedentibus 
inchoamus a dextra et a figura minori; in hac autem specie et in omnibus sequentibus inchoamus a sinistra et a figura majori : unde versus-

Subtrahis aut addis a dextris vel mediabis ;

A leva dupla, divide, multiplicaque:

Extrahe radicem semper sub parte sinistra. ${ }^{1}$

Si enim velis incipere duplare a prima figura, continget idem bis duplare. Et licet aliquo modo possumus operari incipiendo a dextris, tum difficilior erit operatio et doctrina. Si igitur velis aliquem numerum duplare, scribatur ille numerus per suas differentias, et dupletur ultima figura. Ex illa igitur duplatione aut excrescit digitus, aut articulus, aut numerus compositus. Si digitus, loco illius deletæ scribatur digitus excrescens. Si articulus, loco illius deletæ scribatur cifra, et transferatur articulus, versus sinistram. Si numerus compositus, loco illius deletæ scribatur digitus qui est pars illius compositi et sinistretur articulus. Hoc facto, duplanda est ultima figura, et quicquid excreverit negociandum est, ut prius. Si vero occurrerit cifra, relinquenda est intacta. Sed si aliquis numerus cifræ debeat loco illius

${ }^{1}$ In Dionysii algorismo. MS. Bib. Reg. Mus. Brit. 8. c. iv. Vide Arithmeticæ Brevis Introductio, per A. Lonicerum, $12 \mathrm{mo}$. Francof. 1551:

\section{"Addas, subducas a dextris multiplicesque;}

Dividit ac mediat deinde sinistra manus."

Vide Cirveli Algorismus, 4to. Par. 1513. Buclæi Arith. Memor. 12mo. Cantab. 1613; et Arithmetica Speculativa Bravardini, 4to. Par. 1500. 
deletæ scribatur numerus addendus, eodem modo negociandum est ut prius de omnibus: probatio hujus talis est: si recte mediaveris, dupla et occurrent eædem figuræ quas prius habuisti. Est enim duplatio mediationis probatio et converso.

\section{VI.-Multiplicatio.}

Multiplicatio est numeri per se vel per alium, propositis duobus numeris, est tertii inventio qui contineat alterum illorum quot continentur unitates in reliquo. In multiplicatione duo sunt numeri necessarii, scilicet, numerus multiplicandus et numerus multiplicans. Numerus multiplicans adverbialiter nuncupatur. Numerus vero multiplicandus nominalem recipit appellationem: potest et jam tertius numerus assignari qui productus dicitur, perveniens ex ductione unius in alterum. Notandum est quod de multiplicante potest fieri multiplicandus et econverso, manente semper eadem summa, omnis numerus in seipso convertitur multiplicando. Sunt autem sex regulæ multiplicationis, quarum prima talis est: quinam digitus multiplicat digitum, subtrahendus est minor digitus ab articulo suæ denominationis per differentiam majoris digiti ad denarium, denario simul computato. Verbi gratia, si vis scire quot sunt quater in octo, vide quot sunt unitates intra octo et decem, denario simul computato, et patet quot sunt duo: subtrahatur ergo quaternarius a quadraginta bis et remanent 
32 , et hæc est summa totius multiplicationis. Similiter quando digitus multiplicat seipsum. Quando autem digitus multiplicat numerum compositum, ducendus est digitus in utramque partem numeri compositi, ita quod digitus in digitum per primam regulam, et digitus in articulum per secundam regulam; postea producta conjungantur simul, et erit summa totius multiplicationis. Quando articulus multiplicat articulum, ducendus est digitus a quo denominatur ille articulus in digitum a quo denominatur reliquus. Quando articulus multiplicat numerum compositum, ducendus est digitus articuli in utramque partem numeri compositi ; conjungantur producta, et patebit summa totius. Quando numerus compositus multiplicat numerum compositum, ducenda est utraque pars numeri multiplicantis in utramque partem numeri multiplicandi et sic ducetur digitus bis, quia semel in digitum et semel in articulum. Articulus similiter bis, quia semel in digitum et iterum in articulum : hic tamen ubique articulus non ad principales extenditur articulos. Si igitur velis aliquem numerum vel per se vel per alium multiplicare, scribe numerum multiplicandum in superiori ordine per suas differentias, numerum vero multiplicantem in inferiori per suas differentias, ita tamen quod prima figura inferioris ordinis sit sub ultima superioris. Hoc facto, ducenda est ultima multiplicantis in ultimam multiplicandi. Ex illo igitur ductu aut excrescit digitus, aut 
articulus, aut numerus compositus. Si articulus, ex directo figuræ multiplicantis scribatur cifra, et transferatur articulus versus sinistram. Si digitus, ex directo super positionem figuræ multiplicantis scribatur digitus excrescens. Si numerus compositus, ex directo figuræ multiplicantis scribatur digitus illius numeri compositi, et sinistretur articulus, ut prius. Hoc autem facto, ducenda est ultima numeri multiplicantis in ultimam multiplicandi, et quicquid inde excreverit, negociandum est, ut prius; et sic fiat de omnibus aliis numeri multiplicantis, donec perveniatur ad primam multiplicantis, quæ ducenda est in ultimam multiplicandi, et ex illo ductu aut excrescit digitus, aut articulus, aut numerus compositus. Si digitus, loco superioris deletæ scribatur digitus excrescens; si articulus, loco superioris deletæ scribatur cifra et sinistretur articulus: si numerus compositus, loco superioris deletæ scribatur digitus qui est pars illius numeri compositi et sinistretur articulus, ut prius. Hoc autem facto, anteriorandæ sunt figuræ numeri multiplicantis per unam differentiam, ita quod prima multiplicantis sit sub penultima multiplicandi, reliquis similiter per unum locum anterioratis. Quo facto, ducenda est figura ultima multiplicantis in illam figuram sub qua est prima figura multiplicantis, et ex illo autem ductu aut excrescit digitus, aut articulus, aut numerus compositus. Si digitus, ex directo figuræ suprapositæ addatur: si articulus, transferatur versus sinis- 
tram, et figura directi supraposita relinquatur intacta; si numerus compositus, addatur digitus suprapositæ figuræ et sinistretur articulus. Similiter quælibet figura numeri multiplicantis in penultimam multiplicandi donec perveniatur ad primum multiplicantis, ubi operandum est ut prius, vel quemadmodum determinatur de primis; deinde anteriorandæ sunt figuræ per unicam differentiam, ut prius. Nec cessandus est a tali anterioratione nec a tali ductu. Quovis quælibet figura numeri multiplicantis ducatur in quamlibet figuram numeri multiplicandi. $\mathrm{Si}$ autem contingat quod prima figura numeri multiplicantis sit cifra et ei supponatur figura significativa, loco illius superioris deletæ scribenda est cifra. Si autem contingat quod cifra sit inter primam figuram et ultimam multiplicandi, anteriorandus est ordo figurarum per duas differentias, quamvis ex ductione alicujus figuræ in cifram nihil resultat. Ex perdictis ergo patet quod si prima figura numeri multiplicandi sit cifra, sub ea non debet fieri anterioratio. Sciendum autem quod in multiplicatione et divisione et radicum extractione competenter potest relinqui spacium vacuum inter duos ordines figurarum, ut ibi scribatur, quod pervenit addendum aut subtrahendum ne aliquid memoriæ intercidatur. ${ }^{2}$

2 Vid. Piscatoris Compendium Arithmeticæ, 12mo. Lips. 1592. Ursini Systema Arithmeticæ, 12mo. Colon. 1619. Frisii Arith. Pract. Methodus facilis, 12mo. Colon. 1592. Tonstallus de Arte Supputandi, 4to. Lond. 1522. 


\section{VII.-Divisio.}

Divisio $^{3}$ numeri per numerum est, propositis duobus numeris, majorem in tot partes distribuere quot sunt unitates in minori. Notandum ergo quod in divisione, tres numeri sunt necessarii; scilicet, numerus dividendus; numerus dividens, sive divisor; et numerus denotans quotiens. Numerus autem dividendus semper debet esse major, vel saltem par divisori, si debeat fieri divisio per integra. $\mathrm{Si}$ velis igitur aliquem numerum per alium dividere, scribe numerum dividendum in superiori ordine per suas differentias, divisorem vero in inferiori ordine per suas differentias, ita quod ultima divisoris sit sub ultima dividendi, penultima sub penultima, et sic de aliis, si competenter fieri possit. Sunt autem duæ causæ quare ultima sub ultima inferioris ordinis non possit collocari, quia aut ultima inferioris ordinis non possit subtrahi ab ultima superioris quod est minor inferiori, aut quæ licet ultima superioris possit subtrahi a sua superiori: reliquo tamen non possunt subtrahi a figuris sibi suprapositis, si ultima inferioris sit par figuræ suprapositæ. His itaque ordinatis,

3 “Numeratio conjuncta, est multiplicatio aut divisio: multiplicatio est, qua multiplicandus toties addatur, quoties unitas in multiplicante continetur, et habetur factus: divisio est, qua divisor subducitur a dividendo quoties in eo continetur, et habetur quoties." - Rami Arithmetica, Edit. 1581, pp. 11 et 14 . 
incipiendum est operari ab ultima figura numeri divisoris, et videndus est quotiens, possit illa subtrahi a figura sibi supraposita, et reliquæ a residuo sibi supraposito, si aliquid fuerit residuum. Viso ergo quotiens, figuræ inferioris ordinis possint subtrahi a suis superioribus, scribendus est numerus denotans quotiens ex directo supraposito illius figuræ sub qua est prima figura numeri divisoris, et per illam dividendæ sunt omnes figuræ inferioris ordinis a suis superioribus. Si autem contingat post anteriorationem quod non quotiens, possit subtrahi ultima figura divisoris a figura sibi supraposita super figuram sub qua est prima divisoris, recte scribenda est cifra in ordine numeri denotantis quotiens, et anteriorandæ sunt figuræ, ut prius; similiter faciendum est ubicunque contingit in numero dividendo quod divisor non possit subtrahi a numero dividendo, ponenda est cifra in ordine numeri denotantis quotiens et anteriorandæ sunt figuræ, ut prius: nec cessandum est a ductu numeri denotantis quotiens in divisorem, nec a ductu divisoris subtrahendæ donec prima divisoris sit subtracta a prima dividendi: quo facto, aut aliquid erit residuum aut nihil: si aliquid sit residuum, reservetur exterius et scribatur in tabula et erit semper unius divisoris. Cum igitur facta fuerit talis divisio, et probare volueris utrum benefeceris, multiplica numerum denotantem quotiens per divisorem et redibunt eædem figuræ quas prius habuisti, si nihil fuerit 
residuum; sed si aliquid fuerit residuum, tunc cum additione residui redibunt eædem figuræ quas prius habuisti; et ita probat multiplicatio divisionem, et econtrario. Sed si facta multiplicatione, dividatur productum per multiplicantem, exibunt in numero denotante quotiens figuræ numeri multiplicandi.

\section{VIII.-Progressio. ${ }^{4}$}

Progressio est numerorum secundum æquales excessus ab unitate vel binario sumptorum aggregatio ut universorum summa compendiose habeatur. Progressionum alia naturalis sive continua, alia intercisa sive discontinua. Naturalis est quando incipitur ab unitate et non omittitur in accensu aliquis numerus, ut 1.2. 3.4.5.6. et cætera; et sic numerus sequens superat numerum precedentem unitate. Intercisa est quando omittitur numerus aliquis, ut 1.3.5.7.9. et cætera. Similiter a binario possunt incipi, ut 2.4.6.8. et sic numerus sequens superat precedentem numerum in duobus unitatibus. Notandum quod progressionis naturalis duæ sunt regulæ, quarum prima est

4 “Progressio est numerorum æqualiter distantium in unam summam collectio. Progressio arithmetica continua sive naturalis est ubi post primum characterem nullus intermittitur. Progressio arithmetica discontinua sive intercisa, est figuris æqualiter interceptis numerorum ordo." Hudaldrichus de Arithmetica, $12 \mathrm{mo}$. Frid. 1550, p. 70. Vid. Glareanus de Algorismo, 12mo. Par. 1558, p. 20. 
talis; quando progressio naturalis terminatur in numerum parem, per medietatem ipsius multiplica numerum proximum totali superiorem; verbi gratia, 1.2.3.4. multiplica quinarium per binarium, et exibunt decem, summa totius progressionis. Secunda regula talis est; quando progressio naturalis terminatur in numerum imparem, sume majorem partem illius imparis et per illam multiplica totalem numerum; verbi gratia, 1.2.3.4.5. multiplica quinarium per ipsum trinarium, et resultabunt quidenarius, summa totius progressionis. Similiter de progressione intercisa duæ dantur regulæ, quarum prima talis est; quando progressio intercisa terminatur in numerum parem, per medietatem illius multiplica numerum proximum medietati superiorem, ut, 2.4.6. multiplica quaternariem per ternarium, et resultabunt duodecim, summa totius progressionis. Secunda regula talis est; quando progressio intercisa terminatur in numerum imparem, multiplica majorem portionem per se ipsam; verbi gratia, 1.3.5. multiplica ternarium per se et exibit nonenarius, summa totius progressionis.

\section{IX.-Perambulum ad Radicum Extractionem.}

Sequitur de radicum extractione, et primo in quadratis: unde videndum est qui sit numerus quadratus et quæ sit radix numeri, et quid sit radicem ejus extrahere. Primo notandum tamen 
est hæc divisio; numerorum alius linearis, alius artificialis, alius solidus. Numerus linearis est qui consideratur tamen penes processum, non habito respectu ad ductionem numeri in numerum, et dicitur linearis, quia unicum tantum habet numerum, sicut linea unicam habet dimensionem, longitudinem sine latitudine. Numerus superficialis est qui resultat ex ductu numeri in numerum, et dicitur superficialis quia habet duos numeros denotantes sive mensurantes ipsum, sicut superficies duas habet divisiones; scilicet, longitudinem et latitudinem. Sed sciendum est qui dupliciter potest numerus duci in numerum aut semel aut bis: si numerus semel ducatur in numerum hoc erit in seipsum vel in alium. Sciendum quod si ducatur in se semel, fit numerus quadratus, qui, diversum scriptus per unitates, habet quatuor latera æqualia admodum quadranguli. Si ducatur in alium, fit numerus superficialis et non quadratus, ut binarius ductus in ternarium constituit senarium, numerum superficialem, et non quadratum; unde patet quod omnis numerus quadratus est superficialis et non convertitur. Radix autem numeri quadrati est ille numerus qui ita ducitur in se, ut bis duo sunt quatuor. Quaternarius igitur est primus numerus quadratus, et binarius est ejus radix. Si autem numerus bis ducatur in numerum, facit numerum solidum, ut dicitur, sicut solidus corpus tres habet dimensiones; scilicet, longitudinem et latitudinem et spissitudinem. Ita numerus iste 
tres habet numeros ducentes in se. Sed numerus potest bis duci in numerum dupliciter, qui quot in seipsum aut in alium. Si igitur numerus bis ducatur in se vel semel in se et postea in suum quadratum sit numerus cubicus, et dicitur numerus cubicus ab nomine cubi quod est solidus. Est autem cubus quidam corpus habens sex super ficies, solidos octo angulos, et duodecim latera. $\mathrm{Si}$ autem aliquis numerus bis ducatur in alium fit numerus solidus et non cubicus; ut bis tria bis constituerunt duodecim. Unde patet quod omnis numerus cubicus est solidus, sed non convertitur. Ex predictis igitur patet quod idem numerus est radix numeri quadrati et cubici, non tamen illius radicis idem est quadratus et cubicus. Cum igitur ex ductu unitatis in se semel vel bis nihil perveniat nisi unitas, sicut dicit Boetius in arithmetica sua, quod omnis unitas potentialiter est numerus omnis, nullus autem auctus. Notandum autem quod inter quoslibet quadratos proximos continget reperire unicum medium proportionale, quod pervenit ex ductu radicis numeri quadrati in radicem alterius. Item inter quoslibet duos cubicos proximos est reperire dicitur medium proportionale, scilicet, minus medium et majus. Minus medium pervenit ex ductu radicis majoris cubici in quadratum minoris. Majus medium est, si ducatur radix minoris cubici in quadratum majoris. Cum igitur ultra summam numerorum solidorum in arte præsenti, non fiat processus, autem quatuor limites nume- 
rorum distinguuntur : est enim limes numerorum ejusdem naturæ extremis contentorum terminis, continua ordinatio ; unde primus limes est novem digitorum continua progressio. Secundus novem articulorum principalium est tertius centenariorum. Quartus novem millenariorum tres limites et resultant incomposites per digitorum appositionem super quam cubum articulorum trium predictorum, ut si alter alteri proponatur. Sed per finalis termini rationem ex millenariorum receptione super se semel per modum quadratorum, aut bis per modum solidorum, resultat penultima et ultimus limes.

\section{X.-Extractio radicum in quadratis.}

Radicem numeri quadrati extrahere est, proposito aliquo numero, radicem quadrati invenire, si numerus propositus quadratus fuerit. Si numerus vero non fuerit quadratus, tunc radicem extrahere est maximi quadrati sub numero proposito contenti invenire. Si velis igitur radicem alicujus numeri quadrati extrahere, scribe numerum illum per suas differentias, et computa numerum figurarum, utrum sit par vel impar. Si par, incipiendum est operari sub penultima. Si impar, ab ultima; et, ut breviter dicatur, incipiendum est a figura posita in ultimo loco impari; sub ultima igitur figura in impari loco posita, inveniendus est quidam digitus, qui ductus in se deleat totum sibi suprapositum respectu sui vel inquan- 
tum vicinius potest; tali igitur invento, ducto digito et a superiori subtracto, duplandus est ille digitus, et duplatum ponendum est sub proxima superioris versus dextram et ejus duplum sub illo. Quo facto, inveniendus est quidam digitus sub proxima figura ante duplatum, qui ductus in duplatum deleat totum suprapositum respectu duplati ; deinde ductus in se deleat totum suprapositum respectu sui vel inquantum vicinius potest: vel potest ita subtrahi digitus ultimo inventus ut ducatur in duplatum vel duplata et postea in se; deinde illa duo producta simul addantur, ita quod prima figura ultimi producti ponatur ante primam primi producti et superiora addatur primæ, et sic de aliis, et subtrahatur simul a totali numero respectu digiti inventi. Si autem contingit quod non possit aliquis digitus inveniri post anteriorationem, ponenda est cifra sub tertia figura versus dextram, et anteriorandum est primum duplatum cum suo subduplo: non cessandum est a talis digiti inventione, nec a digiti inventi duplatione, nec a duplatorum anterioratione, nec a subdupli subduplo positione, donec sub prima figura inventus sit quidam digitus, qui ductus in omnes duplatos deleat totum suprapositum respectu sui vel inquantum vicinius potest. Quo facto, aut aliquid erit residuum aut nihil; si nihil constat, quamvis propositus fuerit quadratus et ejus radix est digitus ultimo inventus cum subduplo vel cum subduplis, ita quod proponatur: si vero aliquid fuerit residuum, 
constat quod numerus propositus non fuerit quadratus. Sed digitus ultimo inventus cum subduplo vel subduplis est radix maximi quadrati sub numero proposito contenti. Si velis ergo probare utrum beneficeris necne, multiplica digitum ultimo inventum cum subduplo vel cum subduplis per eundem digitum, et redibunt eædem figuræ quas prius habuisti, si non fuerit residuum; sed si aliquid fuerit residuum, tunc cum additione illius redibunt eædem figuræ quas prius habuisti.

\section{$\mathrm{XI}$ - Extractio radicum in cubicis.}

Sequitur de radicum extractione in cubicis: videndum est quid sit numerus cubicus et quæ sit radix ejus, et quid sit radicem cubicam extrahere. Est igitur numerus cubicus, sicut patet ex predictis, qui pervenit ex ductu alicujus numeri bis in se vel semel in suum quadratum : radix numeri cubici est ille numerus qui ita ducitur bis in se vel semel in suum quadratum. Unde patet quod numerus cubicus et quadratus eandem habuit radicem sicut supra dictum est. Radicem autem cubicam extrahere est numeri propositi radicem invenire cubicam, si numerus propositus sit cubicus: si vero non sit cubicus, tunc radicem cubicam extrahere est maximi cubici sub numero proposito contenti radicem cubicam invenire. Proposito igitur aliquo numero, cujus radicem velis extrahere cubicam; 
primo computandæ sunt figuræ per quartas vel sub loco ultimo millenarii inveniendus est quidam digitus qui ductus in se deleat totum suprapositum respectu sui vel inquantum vicinius potest. Quo facto, triplandus est ille digitus et triplatum ponendum est sub proxima figura tertia versus dextram et ejus subtriplum sub subtriplo. Deinde inveniendus est quidam digitus sub proxima figura ante triplatum, qui cum subtriplo ductus in triplatum, deinde cum subtriplo ductus in productum deleat totum suprapositum 'respectu triplati. Deinde ductus in se deleat totum suprapositum respectu sui vel inquantum vicinius potest: hoc facto, triplandus est ille digitus iterum et ponendum est triplatum sub tertia figura ut prius, et ejus triplatum sub eo; postea anteriorandum est primum triplatum cum subtriplo per duas differentias. Deinde inveniendus est quidam digitus ante triplatus sub proxima figura, qui cum subtriplis ductus in triplata et postea sine subtriplis ductus in productum deleat totum suprapositum respectu sui vel inquantum vicinius potest. Nec cessandum est a talis digiti inventione, nec a digiti inventi triplatione, nec a triplatorum anterioratione per suas differentias, nec a subtripli subtriplo positione, nec a tali multiplicatione, nec a subtractione, donec perventum fuerit ad primam figuram sub qua inveniendus est quidam digitus qui cum subtriplis ductus in triplata, deinde sine subtriplis ductus in productum deleat 
totum suprapositum respectu sui vel inquantum vicinius potest. Notandum est quod productum perveniens ex ductu digiti inventi in se possunt addi et similiter simul contrahi a tali numero supraposito in respectu digiti inventi : hoc facto, aut aliquid erit residuum aut nihil: si nihil, constat quod numerus propositus fuit cubicus, et ejus radix est digitus ultimo inventus propositus cum subtriplis vel subtriplo, quæ radix si ducatur in se et postea in productum erunt eædem figuræ quas prius habuisti. Si vero fuerit residuum, reservetur idem exterius in tabula, et constat quod ille numerus non fuit cubicus. Sed digitus ultimo inventus cum subtriplo vel subtriplis est radix maximi cubici sibi numero proposito contenti, quæ radix si ducatur in se et postea in productum est maximus cubicus sub numero proposito contentus, et si illo cubico addatur residuum in tabula, erunt eædem figuræ quæ prius fuerunt. $\mathrm{Si}$ autem aliquis digitus post anteriorationem, non inveniri possit, tunc ponenda est cifra sub quarta figura versus dextram et anteriorandx sunt figuræ ut prius. Notandum est, et quod si in numero proposito non est aliquis locus millenarii, incipiendum est operari sub prima figura. De extractione radicum dicta sufficiant. 


\title{
A METHOD USED IN ENGLAND IN THE FIFTEENTH CENTURY FOR TAKING THE ALTITUDE OF A STEEPLE OR INACCESSIBLE OBJECT. ${ }^{5}$
}

\author{
MS. LANSD. MUS. BRIT. 762. For. 23. в.
}

Here foloweth a rule howe a mann stondyng in a playne by a steple or such another thynge of height by lokyng vponn it shall knowe the certentie of the height thereof. First, let a mann consider by his estimacioun howe farre he stondeth from it be it $\mathrm{xx}, \mathrm{xxx}$, or $\mathrm{xl}$ fadam, And thereaboute as he demeth the certentie let hym stonde and there pitche a staffe the vpper poynte thereof to be juste with his yie, he stondyng upp righte therby. And thann let hym leye hym

${ }^{5}$ It is scarcely necessary to observe that this method of proceeding could only have been practised by the more ignorant classes : the English mathematicians of that period were skilful in the application of the quadrant, and all other then known scientific instruments, as may be seen from their numerous works which still remain in manuscript in the various public and private collections of Great Britain. Fuller quaintly remarks, "I never did spring such a covye of mathematicians all at once, as I met with at this time."-History of the Worthies of England. Edit. 1811. Vol. II. p. 413. 
downe alonge upp righte beyonde the staffe from the steple warde his feet juste to the staffe, and whann the staffe so stondeth he lying as is aforesaid, as his yie on the hyghest poynte of the staffe is juste with the height of the heighest poynte of the steple. Than the juste space from his yie as he lyith to the foote of the steple, that is to saye to that parte of the foote which is as litill as the top therof is the juste mesure of the height of the said steple. And if the staff stonde not juste let hymm remeve it till his yie he lying as is aforesaid with the highest poynte of the staf accorde with the highest poynte of the steple. 


\title{
A TREATISE
}

\author{
ON THE
}

\section{NUMERATION OF ALGORISM,}

\author{
FROM A MS. OF THE 14TH CENTURY.
}

To alle suche even nombrys the most have cifrys as to ten. twenty. thirtty. an hundred. an thousand and suche other. but ye schal vnderstonde that a cifre tokeneth nothinge but he maketh other the more significatyf that comith after hym. Also ye schal vnderstonde that in nombrys composyt and in alle other nombrys that ben of diverse figurys ye schal begynne in the ritht syde and so rekene backwarde and so he schal be wryte as thus-1000. the cifre in the ritht side was first wryte and yit he tokeneth nothinge no the secunde no the thridde but thei maken that figure of $\mathbf{1}$ the more signyficatyf that comith after hem by as moche as he born oute of his first place where he schuld yf he stode ther 
tokene but one. And there he stondith nowe in the ferye place he tokeneth a thousand as by this rewle. In the first place he tokeneth but hymself. In the secunde place he tokeneth ten times hymself. In the thridde place he tokeneth an hundred tymes himself. In the ferye he tokeneth a thousand tymes himself. In the fyftye place he tokeneth ten thousand tymes himself. In the sexte place he tokeneth an hundred thousand tymes hymself. In the seveth place he tokeneth ten hundred thousand tymes hymself, \&c. And ye schal vnderstond that this worde nombre is partyd into thre partyes. Somme is callyd nombre of digitys for alle ben digitys that ben withine ten as ix, viii, vii, vi, $v$, iv, iii, ii, $i$. Articules ben alle thei that mow be devyded into nombrys of ten as $\mathrm{xx}, \mathrm{xxx}, \mathrm{xl}$, and suche other. Composittys be alle nombrys that ben componyd of a digyt and of an articule as fourtene fyftene thrittene and suche other. Fourtene is componyd of four that is a digyt and of ten that is an articule. Fyftene is componyd of fyve that is a digyt and of ten that is an articule and so of others ....... But as to this rewle. In the firste place he tokeneth but himself that is to say he tokeneth but that and no more. If that he stonde in the secunde place he tokeneth ten tymes himself as this figure $\mathbf{2}$ here 21. this is oon and twenty. This figure 2 stondith in the secunde place and therfor he tokeneth ten tymes himself and ten tymes 2 is 
twenty and so forye of every figure and he stonde after another toward the lest syde he schal tokene ten tymes as moche more as he schuld token and he stode in that place ther that the figure afore him stondeth: lo an example as thus 9634. This figure of foure that hath this schape 4 tokeneth but himself for he stondeth in the first place. The figure of thre that hath this schape 3 tokeneth ten tyme himself for he stondeth in the secunde place and that is thritti. The figure of sexe that hath this schape 6 tokeneth ten tyme more than he schuld and he stode in the place yer the figure of thre stondeth for ther he schuld tokene but sexty. And now he tokeneth ten tymes that is sexe hundrid. The figure of nyne that hath this schape 9 tokeneth ten tymes more than he schulde and he stode in the place ther the figure of 6 stondeth inne for thanne he schuld tokene but nyne hundryd. And in the place that he stondeth inne nowe he tokeneth nine thousand. Alle the hole nombre of these foure figurys. Nine thousand sexe hundrid and foure and thritti. 


\section{A TREATISE}

ON THE PROPERTIES AND QUALITIES OF GLASSES FOR OPTICAL PURPOSES,

ACCORDING TO THE MAKING, POLISHING, AND GRINDING OF THEM.

BY WILLIAM BOURNE.

FROM MS. LANSD. MUS. BRIT. 121.

EPISTLE DEDICATORY.

To the Right Honorable, and hys singuler good Lorde, Sir Wilyam Cicil, Baron of Burghley, Knight of the moste noble order of the garter, Lorde Highe Treasurer of Englande: Mr. of the Courte of Wardes and Liverys, Chancelour of the Vniversity of Cambridge, and one of the Queens Majestie's Honorable Privy Counsell.

Right Honorable, fynding myself moste deepely bounde, vnto youre Honour, in dyvers respects : And allso youre Honours moste excellent and worthy skilles, and knowledge in all notable, laudable and noble experiences of learning in all maner of causes: And allso, for that of late youre honour hathe had some conference and 
speache with mee, as concerning the effects and qualityes of glasses, I have thought yt my duty to furnish your desyer, according vnto suche simple skill, as God hathe given me, in these causes, Whiche ys muche inferiour vnto the knowledg of those, that ys learned and hathe red suche authors, as have written in those causes, and also have better ability and tyme, to seke the effects, and quality thereof, then I have, eyther elles can, or may, by the meanes of my small ability, and greate charge of children: Whiche (otherwyse) yt ys possible that I shoulde have bene better able to have done a nomber of thinges, that now I must of force leave, that perhapps shoulde have bene. And allso aboute seaven yeares passed, vppon occasyon of a certayne written Booke of myne, which I delivered your honour, Wherein was set downe the nature and qualitye of water: As tuchinge ye sinckinge or swymminge of thinges. In sort youre Honoure had some speeche with mee, as touching measuring the moulde of a shipp. Whiche gave mee occasyon, to wryte a litle Boke of Statick. ${ }^{6}$ Whiche Booke since that tyme, hath beene profitable, and helpped the capacityes, bothe of some sea men, and allso shipp carpenters. Therefore, I have now written this simple, and breefe note, of the effects, and qualityes of glasses, according vnto the several formes, facyons, and makyngs

6 The work here alluded to is probably his "Treasure for Travellers," which was published at London in 1578. 
of them, and allso the foylinges of them. That ys to saye, the foyle or using of them, that yow may not looke thorowe the Glass: Whiche causeth the Glass to cast a beame vnto your eye, acording vnto the shape, or forme of any thinge, yt standeth against yt. And allso the polishing and grynding of glasse, whiche causeth sondry effects: As in ye readinge hereafter dothe appeare the merveylous nature and operation of glasses \&c. I humbly desyring your Honour, to take this simple rude matter in good parte: And to accept yt as my good Will, allthoughe that the matter ys of none importance.

By your Honoures, dutyfully to Commande, W. BOURNE.

\section{CHAPTER I.-Introduction.}

Whereas the eye ys the principall member of the body neyther the Body in respect, coulde not moove any distance, but vnto perrill, yf yt were not for the sighte of the Eye, whose quality ys moste wonderfull, and hathe the largest preheminence of all the members of the body. For that the Eye ys able to discerne and see any thinge, how farr down that the distance ys from yow: Yf the thinge bee of magnitude or bignes, correspondent vnto the distance. Now, this quality of the sighte of the Eye ys of no quantity or bignes: 
But onely the quality of the eye ys to see, and begynneth at a poynte, withoute any quantity or bignes. As for example you may knowe yt by this : Pricke a hoale in any thinge, with the poynte of a fine needle, and then holde that vnto your Eye, and beholde any thinge thorowe the hole, and you may see a greater thinge, if that yt bee any distance from yow: yow may beholde a whole towne, beeynge a greate distance from you, \&c. And for that perspective ys the discerning of any thinge either substancyall or accidentall, accordinge to the bignes, and distance, and hath his boundes, betweene too righte lynes, from a poynte: And so extending infinitely from the sight of the Eye, yt showeth yt self according to the quantity or bignes, correspondent vnto the distance. And for that perspective ys muche amplifyed and furdered by the vertue and meanes of Glasses, I do thinke yt good to shewe the property of glasses: And suche, as touchinge the nature and quality of glasses, commonly called Lookinge Glasses. Whiche are those sortes of Glasses, that have a ffoyle, layde on the backe syde thereof, that causeth the same glasse to cast from yt a beame or shadowe, accordinge vnto the forme of that thinge that standeth ageanst yt shewynge yt vnto the sighte of the eye. Whereof there ys three severall sortes, accordinge vnto the sundry makinge and polisshinge of these glasses: I do not meane sondry sortes of stuffe, ffor that theare ys some sortes of lookinge glasses 
that are made of metalles, which are commonly called steele glasses. But I do meane three sondry sorts of forms of making them. As in the one sorte, the beame will shewe ytself accordinge to the bignes, as yt ys: And in the other sorte yt will shewe ytself less, as in the order of the making of $y t$, the face of a man shall not shewe ytself as broade as the nayle of youre hande. And so accordingly you may make the glasse to shewe the face, at what bignes you lyst, vntill that yt shall shewe the face at inst the bignes thereof. And the thirde sorte of the making of glasses as you may make the glasse, in sorte, that you will make the face as bigg as the whole glasse, howe broade soever that the glasse ys, yow standing at some one assigned distance.

\section{CHAPTER II.}

In what forme to make Glasses, for to have yt shewe yt self, according to the bignes of the thinge.

For to have a Glasse (to shewe the beame vnto the eye of that biggnes that the thinge ys) That glasse must bee made flatt and playne; and being well polysshed, and smoothe, and well foyled on the back syde. Then you standinge righte with the middle thereof, you shall receave a beame vnto your eye of the trewe forme and shape of 
your face, or any thinge, that standeth directly right against yt. But yf that you do stande any thinge oblique, or awrye, so shall you receave the beame, or see any thinge that maketh the lyke triangle, eyther acute, or sharpp, and obtuse or broade; Accordinge vnto the angle: that commeth from youre eye, vnto the glasse. So shall you receave, or see that beame, accordinge vnto the angle on the other syde, whatsoever that yt bee, howe farr soever that thinge ys in distance from the place, or neare hande.

\section{CHAPTER III.}

In what forme to make glasses for to have them shewe the forme or facyon of any thinge less in bignes then yt ys.

To have a glasse to make any thinge shewe smaller then yt ys, That must be in the makinge thereof made hillye or bossy outwardes, and to have the foylle layde on the hollowe or concave syde, and so yt may bee made, that youre face showe in the beame that commeth to the eye, as small as you lyst, or any syse that ys less than your face at your pleasure. And for to have yt shewe very smalle, then let $\mathrm{yt}$ be made half a globe, or boawle, as smalle as a Tennys balle, and so the foylle layde on the concave or hollowe syde. So 
shall the beame that ys cast vnto your eye, shewe your whole face, not to be so bigg as the nayle of your fingeres, and so you may make yt to bee hilly, or bossy outewardes, to have any thinge to shewe of what syse, that you lyst. For if that $\mathrm{yt}$ bee made as half a boawle or globe, Then of what syde soever you doo stande, you shall see youre owne face, or any thinge that standeth right as you do stande: And to bee in swellenes accordinge to the forme of the hylling or bossing outwardes. And allso as many tymes, that you doo see looking glasses, which make the face longer or broder then the forme or proportyon of your face, the reason thereof ys, that yt hilleth or bosseth more one way, then yt dothe another way. And that way that $\mathrm{yt}$ bendeth moste outewardes, that way yt maketh moste narrowest, and that way, that the glasse ys moste myghtest, that way yt sheweth the face moste longest. For yf that a glasse were made righte one way, and rounde outwardes the other way, and the foyle layde on the hollow syde, Then that Glasse woulde make the face, the streighte way, the inst lengthe of the face, and the other way narrowe accordinge vnto the roundinge of the glasse. So that all sortes of Lookinge glasses, that dothe bosse or hyll owtewardes, dothe shewe the thinge less then yt ys, accordinge vnto the bendinge hilling or bossinge outwarde. 


\section{CHAPTER IV.}

In what maner of forme to make Lookinge Glasses, to male any thinge shewe bigger then yt ys.

To make lookinge Glasses for to shewe any thinge bigger then yt ys, That Glasse muste bee made very large : for elles yt will not conteyne any quantitye in sighte; and this glasse must bee Concave inwardes, and well pollyshed of the hollowe or concave syde: and then the foylle must bee layde on that syde that doth swell, as a hyll, and bosse outwarde. And then this glasse, the property of yt ys, to make all thinges which are seene in yt to seem muche bigger then yt ys to the syghte of the Eye, and at some appoynted distance, from the glasse, accordinge to the forme of the hollowness, the thinge will seeme at the biggest, and so yow standinge nearer the thinge will seeme less, vnto the sighte of the eye : so that, accordinge vnto the forme of the concavity or hollownes, and at some appointed distance from hym that looketh into the glasse, And yf that the glasse were a yearde broade, the beame that shoulde come vnto his eye, shall showe his face as broade, as the whole glasse, And to see his face in this glasse, hee must stande righte with the middle of the glasse, $8 c$. And these sortes of glasses ys very necessary for 
perspective: for that yt maketh a large beame, whereby that a small thinge may be seene, at a greate distance from you: and especially to bee amplified by the ayde of other glasses, \&c.

\section{CHAPTER V.}

In what order to make a glass, that yow may looke thorow, that shall forther your sighte, and to have a small thynge to seem bigg, which ys very necessary for perspective: And yt may bee so made, that you may discerne a small thinge, a greate distance, and specyally by the ayde of other glasses.

And nowe furdermore, as I have shewed before, the forme, and facyon of glasses, that dothe reflect a beame from the glasse, commonly called Lookinge Glasses: So in lyke manner I will shewe you the makinge of Glasses called perspective glasses, that do helpe sighte, by the meanes of the beame, that pearceth commonly thorowe the glasse. And first for makinge of the smallest sorte of them, commonly called spectacle glasses. These sortes of glasses ys grounde vppon a toole of Iron, made of purpose, somewhat hollowe, or concave inwardes. And may be made of any kynde of glasse, but the clearer the better. And so the Glasse, after that yt ys full rounde, ys made fast with syman vppon a smalle block, 
and so grounde by hande, vntill that yt ys bothe smoothe and allso thynne, by the edges, or sydes, but thickest in the middle. And then yt ys the quality or property of the Glasse that ys cleare, to shewe all thinge, that ys seene through yt, to seeme bigger and perfecter, then that yow may see yt withoute the Glasse, and the thynner vnto the sydes and edges. And the thicker that yt ys in the middle, the bigger or larger any thinge sheweth vnto the eye, and yf that the glasse bee very cleare, the more perfecter, \&c. And now allso in lyke manner for to make a glasse for perspective, for to beholde, and see any thinge, that ys of greate distance from yow, which ys very necessary: for to viewe an army of men, or any castle, or forte, or such other lyke causes. Then they must prepare very cleare, and white Glasse that may bee rounde, and beare a foote in diameter; as fyne and white Vennys Glasse. And the larger, the better: and allso yt must bee of a good thicknes, and then yt must bee grounde vppon a toole fitt for the purpose. Beynge sett fyrst vppon a syman block, and firste, grynde on the one syde, and then on ye other syde, vntill that the sydes bee very thynn, and the middle thicke. And for that yf the glasse bee very thicke, then yt will hynder the sighte. Therefore yt must bee grounde vntill that the myddle thereof bee not above a quarter of an ynche in thickness: and the sydes or edges very thynne, and so polysshed or cleared. And so 
sette in a frame meete for the purpose for use : so that yt may not be broken. And so this glasse being made in this forme, Then $\mathrm{yt}$ wille have three marvellous operacyons, or qualityes, as hereafter you shall see.

\section{CHAPTER VI.}

The first, and the Principall quality of this Glass, and $y s$, as touchinge perspectyve.

The quality of the Glasse, (that ys made as before ys rehearsed) ys, that in the beholding any thinge thorowe the glasse, yow standinge neare vnto the Glasse, yt will seeme thorow the glasse to bee but little bigger, then the proportion ys of yt: But as yow do stande further, and further from $\mathrm{yt}$, so shall the perspective beame, that commeth through ye glasse, make the thinge to seeme bigger and bigger, vntill suche tyme, that the thinge shall seeme shall seeme ${ }^{7}$ of a marvellous bignes: Whereby that these sortes of glasses shall muche proffet them, that desyer to beholde those things that ys of great distance from them: And especially yt will be much amplifyed and furdered, by the receavinge of the beame that commeth thorow the glasse, somew hatt

7 This repetition of the words "shall seeme" is evidently a mistake, but being in the original MS. I have retained it in the text. 
concave or hollowe inwardes and well polysshed as I will hereafter furder declare.

\section{CHAPTER VII.}

The seconde quality of this glass made in the forme before declared.

The quality of this Glass ys, if that the sunne beames do pearce throughe $\mathrm{yt}$, at a certayne quantity of distance, and that yt will burne any thinge, that ys apte for to take fyer: And this burnynge beame, ys somewhat furder from the glasse, then the perspective beame.

\section{CHAPTER VIII.}

The thyrde quality of this kynde of Glass, that ys grounde, and made in that forme before declared, ys to reverse, and turne that thyng that yow io beholde, thorowe ye glass, to stande the contrary way.

And yf that yow doo beholde any thinge thorowe this Glasse, and sett the glasse furder from yowe then the burninge beame, and su extendinge after that what distance that yow list, all suche thinges, that yow doo see or beholde, thoroughe the glasse, the toppes ys turned downwardes. Whether that yt bee trees, hilles, shippes on the water, or any other thinge what- 
soever that yt be: As yf that yt were people, yow shall see them thoroughe the Glasse, theyre heades downwardes, and theyre feete vpwardes, theire righte hande turned to theyre lefte hande, \&c. So that this kynde of Glasse beynge thus grounde hathe three marvellous qualityes. For at some assigned, or appoynted distance, accordinge vnto the gryndinge of the Glasse, bothe in his diameter, and thicknes in the middle, and thinnes towardes the sydes. That (beholdinge any thinge thorowe the glasse) yt shall make the best perspective beame: So that the thinge that yow doo see thorowe shall seeme very large and greate: and more perfitter withall. And allso standing further from the glasse yow shall discerne nothinge thorowe the glasse: But like a myst, or water: And at that distance ys the burninge beame, when that yow do holde yt so that the sunne beames dothe pearce thorowe yt. And allso yf that yow do stande further from the glasse, and beholde any thinge thorowe the glasse, Then you shall see yt reversed and turned the contrary way, as before ys declared. So that accordinge vnto youre severall standinge, nearer, or furder from the Glasse, beholding any thinge thorowe yt. Suche, yt hathe his perspective beame: and then standinge furder from the glasse, and then all thinges seen thorowe, shall shewe vnto the sighte of your eye, cleene turned, and reversed another way, whatsoever that yt bee. 


\section{CHAPTER IX.}

The effects what may bee done with these two last sortes of glasses: The one concave with a foyle, vppon the hylly syde, and the other grounde and pollisshed smoothe, the thickest in the myddle, and thinnest towordes the edges or sydes.

For that the habillity of my purse ys not able for to reache, or beare the charges, for to seeke thorowly what may bee done with these two sortes of Glasses, that ys to say, the hollowe or concave glasse: and allso that glasse, that ys grounde and polysshed rounde, and thickest on the myddle, and thynnest towardes the sydes or edges, Therefore I can say the lesse vnto the matter. For that there ys dyvers in this Lande, that can say and dothe knowe muche more, in these causes, then I: and specially Mr. Dee, and allso Mr. Thomas Digges, for that by theyre Learninge, they have reade and seene many moo auctors in those causes: And allso, theyre ability ys suche, that they may the better mayntayne the charges: And also they have more leysure and better tyme to practyze those matters, which ys not possible for mee, for to knowe in a nombre of causes, that thinge that they doo knowe. But notwithstanding upon the smalle proofe and experyence those that bee but vnto small purpose, 
of the skylles and knowlledge of these causes, yet I am assured that the glasse that ys grounde, beynge of very cleare stuffe, and of a good largenes, and placed so, that the beame dothe come thorowe, and so reseaved into a very large concave lookinge glasse, That yt will shewe the thinge of a marvellous largeness, in manner vncredable to bee beleeved of the common people. Wherefore yt ys to bee supposed, and allso, I am of that opinyon, that havinge dyvers, and sondry sortes of these concave lookinge glasses, made of a great largeness, That suche the beame, or forme and facyon of any thinge beeynge of greate distance, from the place, and so reseaved fyrste into one glasse: and so the beame reseaved into another of these concave glasses: and so reseaved from one glasse into another, beeynge so placed at suche a distance, that every glasse dothe make his largest beame. And so yt ys possible, that yt may bee helpped and furdered the one glasse with the other, as the concave lookinge glasse with the other grounde and polysshed glasse. That yt ys lykely yt ys true to see a smalle thinge, of very greate distance. For that the one glasse dothe rayse and enlarge, the beame of the other so wonderfully. So that those things that Mr. Thomas Digges hathe written ${ }^{8}$ that his

8 "My father by his continual paynfull practises, assisted with demonstrations Mathematicall, was able, and sundrie times hath by proportionall Glasses duely situate in convenient angles, not onely discovered things farre off, read letters, numbred 
father hathe done, may bee accomplisshed very well, withowte any dowbte of the matter: But that the greatest impediment ys, that yow can not beholde, and see, but the smaller quantity at a tyme.

peeces of money with the very coyne and superscription thereof, cast by some of his freends of purpose vppon Downes in open fieldes, but also seven myles of declared what hath been doon at that instante in private places."-Pref. to Pantometria. Edit. 1571. Sig. A. iii. b. 


\section{J O H A N N I R R B Y N S}

DE COMETIS

C O M M E N T A R I A.

DEDICATIO.

AD invictissimum principem Henricum ejusdem nominis octavum, Serenissimum Anglorum Regem, de cometis commentaria Johannis Robyns sui Alumni, et socii Collegii Omnium Animarum, Oxoniæ.

Quanquam omnes philosophiæ partes (Princeps Illustrissime) tum utiles, tum jucundæ sint; ea tamen philosophiæ portio, quæ de cælis, cælorumque motibus ordine ac influentiis agit, cæteris longe præstantior, multo jucundior, et pene divinum quid nobis esse videtur. Id quod luculentius apparebit, si de his, quæ in aliis philosophiæ partibus tractantur, pauca dixerimus. Et primam a crassissimo, et infimo elemento, scilicet terra, orationem inchoabimus, quæ in media mundi sede collocatur, cernitur solida 
globosa, et undique nutibus suis conglobata; floribus, herbis, arboribus, frugibus ornata, quorum omnium incredibilis multitudo insatiabili varietate distinguitur. Adde etiam fontium gelidas perhennitates; liquores perlucidos amnium; riparum vestitus viridissimos; speluncarum concavas altitudines; saxorum asperitates; impendentium montium sublimitates; immensitatesque camporum. Adde etiam reconditas auri, argenti, metallorumque venas, infinitamque vim marmoris. Quæ vero, et quam varia genera bestiarum, vel cicurum, vel ferarum! qui volucrum lapsus! atque cantus! qui pecudum pastus! quæ vita silvestruum! Quid jam de hominum genere loquar! qui quasi cultores terræ constituti, nec patiuntur eam immanitate belluarum efferari, nec stirpium asperitate vastari. Quorumque operibus agri, insulæ, littoraque collucent, distincta tectis et urbibus. Jam de liquidibus et fusilibus elementi (maris inquam) pulchritudine pauca dicamus oportet. Cujus quidem maris speciem, et animantium quæ in eodem continentur, satis admirari nequeo. Nam ipsum mare undique terram circumfluens, continentes, insulas, peninsulas, et isthmos efficit, et quatenus diversas alluit regiones, et diversa sortitur nomina; ut mare Britannicum, Gallicum, Libicum, Punicum, et cætera. Ac ita quidem terram appetens circumquaque littoribus claudit, et quasi una ex duabus naturis conflata videatur. Quid de piscibus, belluisque marinis dicam? 
Quot genera, quamque disparia, partim submersarum, partim fluitantium, partim innatantium belluarum, partim ad saxa nativis testis inhærentium? De quarum generatione, proprietatibus, et natura, Aristoteles omnium philosophorum facile princeps in historia naturali acutissime disputat. Exinde mari finitimus est aer; cujus suprema portio purior quidem, et sincerior, cœli orbiculationem (sicuti et ipse ignis) subsequitur. Media vero aeris plaga quæ (ut doctiores sentiunt) non parum frigescit, aptior deputatur locus, ubi vapores elevati in nubes concrescant. Inibi etiam fulmina, fulgetra, et tonitruum sedes sibi peculiares vendicant. At infima aeris regio, quæ partim terræ, partim aquatico elemento conterminata junctaque cernitur, avium volatus sustinet, et salutarem, vitalemque spiritum animantibus quidem terrestribus ministrat. Jam ab aere ad ignem postea nostra demigrabit oratio, qui, ex elementis in supremo ac maxime sublimi loco constitutus, aerem in sua concavitate fovens, orbiculariter complectitur. Sicut aer aquam, et aqua terram undique circuit, nisique una pars terræ propter vitam quorundam animantium tuendam aquis discooperta relinquitur. Neque sentiendum est, qua deus et natura inaniter, ac superflue hoc quartum corpus simplex scilicet ignem superaddiderunt. Aeris enim caliditas ab aquæ terræque frigiditate ilico consumeretur, nisi superior ignea vis calefactiva aerem refocillaret. Præterea terræ siccitas ab aere et aqua 
facillime obrueretur, nisi ignis vim suam arescen. tem emittens, aeris humiditatem deliniret. Hactenus succincte de elementis, cæterisque corporibus, quæ infra sphæram activorum et passivorum continentur. Quarum rerum scientia, si (ut revera est) jucunda et delectabilis fuerit, quid de illorum corporum cognitione, quæ cœlestia æternaque esse feruntur sentiendum est? A quorum influentiis et virtutibus tum elementata (ut ita dicamus) suum regimen sortiuntur. $\mathrm{Ab}$ istis enim orbis terrarum plagæ ac regiones habitatæ quibusdam certis temporum vicibus suas magnas hyemes et æstates (ut Aristotelico utar verbo) recipiunt. Magna autem æstas dicitur cum aliqua provincia ex nimia siccitate et fervore ita sterilescit, ut diutius inhabitatores fovere nequeat. Versa ince, magnam hiemem alicujus regionis appellamus, cum humectantes cœlorum influentiæ sic in eadem regione sæviunt, ut terra fluctibus et aquis penitus obruatur; id quod ab aliquibus vocatur diluvium particulare: et non solum istæ prodigiosæ mutationes cœlorum constellationibus tanquam causis attribuuntur, verum etiam quæ diversæ regiones diversa progignunt, corporum cœlestium benignitati aut asperitati primitus ascribitur. Quælibet enim terræ habitabilis portio, suos fructus et fruges, arbores, herbas, ac frutices, lapides etiam pretiosos et mineralia, pro cœli qualitate et influentiis producit. Quid de fertilitate et abundantia, pace atque tranquillitate, fame, bello, pestilentia, et brutorum animan. 
tium strage dicam? quid de sectis, legibus, civitatibus, imo et regnis integris loquar? Quorum omnium fælicitas et infælicitas, mala, damna, et infortunia, successiones, prosperitates, et bona, dispositive saltem a cœlorum constellationibus dependent. Nec minorem certe potestatem in liquido elemento (inquam) in mari influentiæ colestes exercent. Maris enim fluxus, et refluxus æstuosi, in istis fretorum angustiis, a virtutibus lunæ demanant. Præterea piscium et marinarum belluarum ortus, et interitus, augmentationes, diminutiones, et alterationes; necnon eorundem copia, ac penuria, astrorum virtutibus (omnium doctissimorum consensu) ascribuntur. At in aere quam manifestum imperium habent sidera, quorum præsentia vel absentia efficitur, ut idem aer nunc fulgentissima luce splendescat, nunc obscurus et tenebrosus relinquatur. Sol etenim exoriens, suis clarissimis radiis aerem illustrans, diem conficit, et cum primum a nobis recesserit subter cardinem occidentalem......., subrepta nox, quippe quæ nil aliud est, quam ut aer (propter solis sub orizonte dilapsum) tenebris offundatur. Rursus et a solis cursu sub zodiaco quatuor anni tempora, ver, æstas, autumnus, et hyems proficiscuntur. In quibus equidem temporibus sol aerem et cætera elementa tum tristitia quadam contrahit, tum vicissim ita lætificat, ut cum ipso cœlo exhilarata esse videantur. Nolim hic in cæterarum stellarum (quæ erraticæ dicuntur) ratione, ordine et influentiis multus videri, qua- 
rum tantus est concentus ut cum summa Saturni infrigidet, media Martis accendat, his interjecta Jovis stella temperet et illuminet, infraque Martem tres soli obediunt; Luna, Venus, et Mercurius. Et hæ omnes stellæ quas errores appellamus, iisdem vagantur spatiis, quibus et sol, et eodem modo circa terram agitatæ oriuntur, et occidunt, quarum motus nunc incitantur, nunc retardantur, suisque aspectibus et influentiis, (secundum quod sub variis discurrant signis) quatuor anni tempora nunc calidiora, nunc frigidiora, nunc humidiora, nunc sicciora redeunt: qua contemplatione nihil pulchrius, nihil admirabilius esse potest. Quid de gelu, nive, grandine, ventis, pluvia tonitruo, fulmine, fulgetro, stellis item caducis et per aerem discurrentibus dicam? quæ omnia ab astrorum constellationibus progrediuntur. Postremo et illa crinita sidera famosa quidem et portentosa cœlestium stellarum vires, causam suæ generationis, et, si rarius spectantur, æque naturaliter sibi, vendicant, atque ea quæ ab oculis quotidie videntur. Sed plebei quamvis numerosa rerum naturalium multitudo recitari possit, quarum causæ secretiores et magis abditæ sunt, tamen ob insolitam ipsius rei faciem maximopere cometas admirantur. De quibus siquidem cometis tua sacrosancta majestas voluit, ut a nobis quædam commentaria in lucem æederentur. Id quod non hac quidem de causa factum erat (certissime scio) ut in his nostris perlegendis, tua sacrosancta majestas quidpiam eruditionis exhauriret, sed 
aliorum consulens utilitati. Ut qui harum rerum (de quibus tractamus) minus essent periti ex nostris commentariis aliquid saltem adipisci possent. Non enim incognitum est (eruditissime Princeps) quam singularis in scientiis mathematicis tua fuerit doctrina. Id quod ex illis disputationibus manifestissime mihi perspectum erat, quas de cometarum naturis et effectibus tum Woydstokiæ, tum Bokynghamiæ nobiscum habuisti, quis enim invenire poterat argutius, quis colligere veruosius, quis explicare venustius ? In aliis vero scientiis et potissime theologia (serenissime Rex) quam præstantissima tua fuerit cognitio, nihil dicturus sum. Opera enim ea quæ a tua sacrosancta majestate edita sunt, sufficienter ostendunt. In quibus equidem operibus (ut illud quod sentio ingenue dicam) nec Augustino, nec Hieronimo cædere videris. Nam quam caste quam nitide, quam polite omnia mihi disputantur, solidi, succi, et nervorum plena, sed temperabo me a laudibus. Scio etenim, scio (laudatissime Princeps) quam nolunt laudari hi, qui laudes maximæ merentur omnium.

[From what is here given the nature of the work may be seen, and I do not think it as a whole necessary to be printed in this place.-ED.] 


\section{T W 0 T A B L E S :}

ONE SHEWING THE TIME OF HIGH WATER AT LONDON BRIDGE, AND THE OTHER THE DURATION OF MOON LIGHT.

FROM A MS. OF THE 13TH CENTURY.

Bib. Cott. Mus. Brit. Jul. D. vii. Fol. 45, b.

FLOD AT LONDON BRIGGE.

\begin{tabular}{|c|c|c|c|c|c|}
\hline 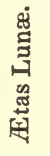 & 密 & 苞 & 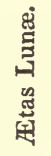 & 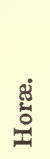 & 胥 \\
\hline 1 & 3 & 48 & 16 & 3 & 48 \\
\hline 2 & 4 & 36 & 17 & 4 & 36 \\
\hline 3 & 5 & 24 & 18 & 5 & 24 \\
\hline 4 & 6 & 12 & 19 & 6 & 12 \\
\hline 5 & 7 & 0 & 20 & 7 & 0 \\
\hline 6 & 7 & 48 & 21 & 7 & 48 \\
\hline 7 & 8 & 36 & 22 & 8 & 36 \\
\hline 8 & 9 & 24 & 23 & 9 & 24 \\
\hline 9 & 10 & 12 & 24 & 10 & 12 \\
\hline 10 & 11 & 0 & 25 & 11 & 0 \\
\hline 11 & 11 & 48 & 26 & 11 & 48 \\
\hline 12 & 12 & 36 & 27 & 12 & 36 \\
\hline 13 & 1 & 24 & 28 & 1 & 24 \\
\hline 14 & 2 & 12 & 29 & 2 & 12 \\
\hline 15 & 3 & 0 & 30 & 3 & 0 \\
\hline
\end{tabular}

QUANTUM LUNA LUCET IN NOCTE.

\begin{tabular}{|c|c|c|c|c|c|}
\hline 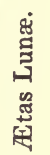 & غ્்ّ & 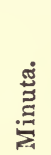 & 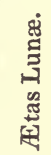 & 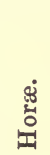 & 焉 \\
\hline 1 & 10 & 48 & 16 & 11 & 12 \\
\hline 2 & 1 & 36 & 17 & 10 & 24 \\
\hline 3 & 2 & 24 & 18 & 9 & 36 \\
\hline 4 & 3 & 12 & 19 & 8 & 48 \\
\hline 5 & 4 & 0 & 20 & 8 & 0 \\
\hline 6 & 4 & 48 & 21 & 7 & 12 \\
\hline 7 & 5 & 36 & 22 & 6 & 24 \\
\hline 8 & 6 & 24 & 23 & 5 & 36 \\
\hline 9 & 7 & 12 & 24 & 4 & 48 \\
\hline 10 & 8 & 0 & 25 & 4 & 0 \\
\hline 11 & 8 & 48 & 26 & 3 & 12 \\
\hline 12 & 9 & 36 & 27 & 2 & 29 \\
\hline 13 & 10 & 24 & 28 & 1 & 36 \\
\hline 14 & 11 & 12 & 29 & 0 & 48 \\
\hline 15 & 12 & 0 & 30 & 0 & 0 \\
\hline
\end{tabular}




\title{
A TREATISE
}

ON THE

\section{MENSURATION OF HEIGHTS AND DISTANCES.}

\author{
FROM A MS. OF THE 14TH. CENTURY.
}

Bib. Sloan. Mus. Brit. 213. xiv. Fol. 120.

Nowe sues here a Tretis of Geometri wherby you may knowe the heghte, depnes, and the brede of mostwhat erthely thynges.

Geometri $^{9}$ es saide of pis greke worde geos. pat es erthe on englisch. and of pis greke worde

9 Vid. MS. Bib. Reg. Mus. Brit. 17 A. 1. f. $2^{\text {b}}-3$.

"The clerk Euclyde on pis wyse hit fonde Thys craft of gemetry yn Egypte londe Yn Egypte he tawghte hyt ful wyde, Yn dyvers londe on every syde.

Mony erys afterwarde y vnderstonde Gher pat pe craft com ynto pys londe. Thys craft com ynto England, as y ghow say, Yn tyme of good kyng Adelstones day."

This notice of the introduction of Euclid's Elements into England, if correct, invalidates the claim of Adelard of Bath, who has always been considered the first that brought them from abroad into this country, and who flourished full two centuries 
metros. pat es mesure on englisch. pan es geometri als erthly mesure. for it es one of pe sevene science techyng to mesure pe erth in heght. depnes and brede. and length. This Tretis es DEPARTED in THRE. pat es to say. hegh mesure.

after the "good kyng Adlestone." Adelard translated the Elements from the Arabic into Latin, and early MSS. of the translation occur in so many libraries, that we may fairly conclude that it was in general circulation among mathematicians for a considerable time after it was written. Tiraboschi was the first who remarked, that the translation attributed to Campanus, was in reality Adelard's, with a commentary by the former, (Libri Hist. des Mat. tom. II. p. 48); there are also several MSS. in the titles to which this is expressly stated, (MS. Bib. Bodl. Seld. Arch. B. 29. MS. Bodl. 3623. MSS. Paris, Lat. 7213, 7214, 7215. MS. Harl. Mus. Brit. 5266 : “per Adelardum Bathoniensum de Arabico in Latinum translatus, cum Commento Campani Novariensis."). In the Library of Queens' College, Cambridge, there was formerly a MS. entitled "Geometria Euclidis cum Commentario Adelardi" (Lelandi Collect. tom.iii. p. 19), and Chasles (Aperçu Historique, p. 509,) mentions one in the library of the Dominicans of St. Marc at Florence, under the same title; this would appear to intimate that the commentary is also by Adelard, and many MSS. in which the name of Campanus does not appear, contain the commentary, (MS. Oxon. in Coll. S. Trin. 30, iv. MS. Harl. Mus. Brit. 5404. MS. Bib. Pub. Cant. Dd. 12, 61). Doctor John Dee, in the Catalogue of his Collection of MSS. (MS. Harl. 1879. MS. Bib. Trin. Coll. Cant. Collect. Gal. O. 4, 20. MS. Ashm. 1142.) gives the title of one, in which the books of Euclid on Optics and Catoptrics, as well as the Elements, appear under Adelard's name.

There have been two independent notices of the plagiarism of Campanus; one by Charles Butler, (the author of the "Introduction to the Mathematics," 8vo. 1814,) in some MS. papers in the Editor's possession: the other by the Author of the article Geometry, in the "Penny Cyclopædia." 
playne mesure. and depe mesure. First foryi shewe we hegh mesure. pat es to say howe any thynge pat has heght may be met howe hegh it es. and pis may be done in many maneres. first perfor schewe howe it may be done by pe quadrant. When you wille wite be heghte of any thyng pat you may negh. biholde pan pe heght of pat thyng by bothe holes of pe quadrant and come toward and go froward til pe perpendicle pat es to say pe threde whereon pe plumbe henges falle vpon pe mydel lyne of pe quadrant. pat es to say pe 45 degre. pan take als mykel lande behynde ye as fro pethen to pe erthe and marke wele pat place. pan mete howe many fete are bytwene pi mark and pe fondement of pat thyng whos heght you sekest. and sekirly so many fote heght it es. Also when you wilt wite pe heght of any thynge by pe quadrant. biholde pe heght of pat thyng by bothe pe holes. and byholde vpon what place of pe quadrant pe perpendicle falles. for ouper it wille falle on pe vmbre toward or on pe vmbre froward. and if it falle vpon pe vmbre toward biholde vpon whilk poynte of pat vmbre pe perpendicle falles. pan mesure pe distaunce pat es to say pe space betwene ye and pat thyng whos heght you sekes, and when you has so done pan multiply you by 12 pat same mesure. pan al pat comes of pat multiplyeng departe you by pe nonmbre of pe poyntes of pe vmbre. and to alle pat comes pereof set pe quantite of pin heghte. and set al pis togydere. and pan you has pe 
heght of pe thyng whos heght you sekes. If peraventure pe perpendicle falle vpon pe vmbre froward biholde pan pe poyntes pereof and torne pem into pe poyntes of pe vmbre toward and do furth pan as we taght byfore and pus sekirly you sale have pe heght of pe thyng whos heght you sekes. namely so pe space be playne bitweene pe and it. Note you pat pe quadrat. pat es to say 4. square whilk es descryvede pat es to say schewed in pe quadrant has tuo sides. pat es to say pe side of pe vmbre toward. and pe side of pe vmbre froward. and aper of pese 2 sides es departed in 12 even parties. When you holdes pe cone of pe quadrant. pat es to say pe cornel of pe quadrant even vpryght in whilk cornel es pe nayle whereby pe perpendicle henges. pan pe circumferens. pat es to say pe cumpasse es toward pe erth. pan pat side of pe quadrat whilk es nere ye es called pe vmbre toward and pat oper side es called pe vmbre froward. and pe 12 departynges of aiper of po sides are called poyntes. pan es a poynte pe twelft parte of any thyng. namely of ouper side of pe quadrat in pe quadrant. Also when pe heght of pe sonne es more pan 45 degres. pan pe perpendicle falles vpon be vmbre toward. And ageynward when pe heght of pe sonne es less pan 45 degrees. pan pe perpendicle falles vpon pe vmbre froward. When sothly pe heght of pe sonne es even 45 degrees. pan pe perpendicle falles even vpon pe 45 whilk es pe medil lyne. If you may noght negh pe thyng pat you wolde 
mesure for letting of water or summe oper thyng bitwene. pan biholde pe heght pereof by bothe pe holes. and biholde pe nonmbre of pe poyntes of pe vmbre toward. namely vpon whome pe perpendicle falles. pan set $\mathrm{D}$ for a mark in pat place where you stondes pan. go ferre or nerre pat thyng whos heght you sekes. and pat by an evene lyne and beholde este pe forsaide heght by bothe holes. pan pere stondyng seke pe nonmbre of pe poyntes of pe vmbre toward. and set pere $\mathrm{C}$ for anoper mark. pan mesure howe many fete are bitwene pise tuo markes D and $\mathrm{C}$ and kepe pat wele in pi mynde. pan abate pe lesse nonmbre of pese tuo in pe vmbre toward fro pe more and kepe wele pe difference bytwene po tuo nonmbres. pan multiplie by twelve pe distaunce bitwene pe forsaide $\mathrm{D}$ and $\mathrm{C}$ and alle pat comes of pat multeplyeng departe you by pe distaunce of pe poyntes. and to pat pat leves over. set als mykel as fro pethen to pe erthe and pan sekirli you has pe heght of pat thynge. bot loke pe holes of pi quadrant be right straite and elles you may lightly be deceyvede. Peraventure you standes in an aley. and pe thyng pat you wolde mete es $\mathrm{vp}$ on an hegh hille. first pan biholde pe heghte of pe hille by both pe holes of pe quadrant. and pat by tuo stondynges of $\mathrm{D}$ and $\mathrm{C}$ as we taght nowe next bifore. and marke pat wele in pi mynde. pan biholde in pe same wise pe heght of the hille and of pat same thyng togedire. pan abate pe heght of pe hille 
fro al pat remenant and pan sekirly hast ou pe heght of pat thyng. If peraventure pe contry es hilly. pan do pat pe perpendicle falle even vpon pe begynnyng of pe side of pe vmbre froward. pan se by bothe holes in pe thyng to be mesured pe poynte pat es called $\mathrm{A}$ and do as we taght bifore. and pat leves after pi wirkyng es pe heght fro A poynte to pe heght of pe thyng: bot pan salt you noght set pereto pe heght of pi stature. Parcas you woldest mesure pe heght of a thyng by the schadowe pereof. pan abyde til pe sonne be in pe heght of fyve and fourti degrees. pan mesure pe vmbre of pat thyng and pat es pe heght pereof. If you wilt mesure pe heght of any thyng by pe schadowe pat es to say pe vmbre pereof in ilk houre pan do pus. mesure pe vmbre pat es to say pe schadowe of pat thyng. and multiply pat by 12 and al pat departe pan by pe poyntes of pe vmbre toward. and pe nonmbre howe ofte euer it be es pe heght of pat thyng if pe perpendicle falle vpon pe vmbre toward. If pe perpendicle falle vp pe poyntes of pe vmbre froward. pan multeply pe vmbre. pat es to say pe schaddowe by pe poyntes of pat vmbre. and al pat departe by 12 and pe nonmbre howe oft it be. es pe heght of pat thyng. Or if you wilt. lede pe poyntes of pe vmbre froward into pe poyntes of pe vmbre toward. and pan multeply pe vmbre. pat es to say pe schaddowe of pat thyng by 12 and pan al pat departe by pe 
poyntes of pe vmbre ladde. Whilk after pe ledying are poyntes of pe vmbre toward. Take pe poyntes of the vmbre pus. late pe sonne benies passe by bothe holes. and mark where pe perpendicle falles. pan counte pe poyntes fro be begynnyng of pe side of pe vmbre to pe touche of pe perpendicle. and po are pe poyntes of pe vmbre. pat es to say pe schadowe. What poyntes ever yei be. wheper of pe vmbre toward or froward. When any thynge es whose hight you wilt mesure by pe schad. dowe pereof and a zerde. pan rere even vp a zerde vpon pe playne grounde were pe ende of pe schadowe of pat thyng whilk you wille mesure, so rere it pat pe one parte of pame zerde falle vpon pat schadowe. and pe oper part of pat zerde falle withouten. and mark pe place in pe zerde where pe schadowe begynnes to touche it. and by pe quantite of the zerde whilk es bitwene pe touche of pe schadowe in pe zerde and pe playne. multeply pe quantite of al pe schadowe whilk es bitwene pe lower party of pe thyng to be mesured and be toppe of pe schadowe in pe playne. and depart pan al pat by pe quantite of pe schadowe whilk es bitwene pe toppe of pe schadowe and pe zerde. and pe nonmbre pat pan comes es pe heght of pat thyng. Also if you wilt mesure pe heght of a thyng by pe schadowe in ilk houre of pe day. take a zerde of two fote longe or thre. and on a playne rayse it even vp. and 
pan mesure pe schadowe of it. pan mesure pe schadowe of pat thyng to be mesuride. and multiply pat by pe length of pe zerde. and pan departe al fat by pe schadowe of pe zerde and pat nonmbre howe ofte it be es pe heght of pat thyng. If you wilt have pe heght of any thyng wantyng grounde. as if you be in an house and wolde wite howe ferre were any thyng beyng in pe rofe. Take a table and rayse it vp a litel fro pe erthe. so pat you may se pat ilk thyng bitwene pe erthe and pat table. pan take a reulure and continu it to pe table. pat es to say side to side. and pan se by al pe reulure pe thyng to be mesurede. and pan drawe a lyne in pe table by pe reulure. este do pe same in anoper site. pat es to say place of pe table. and make anoper lyne. pan mesure pe heght whilk es bitwene pe hyhere parte of pe table and pe erthe. and pat mesure sale be callede pe heght kept. pan set pe table on pe erthe and take tuo thredes and put pat one in pat one lyne. and pat oper threde in pat oper lyne. pan make a mark pere as pise tuo thredes metes. pan mesure pe length bitwene pe mark and pe table. and set pereto pe heght kept. and pan hast ou pe heght of pat thyng. If you wilt mesure pe heght of any thyng withouten quadrant and withouten schadowe. rayse evene $\mathrm{vp}$ a rodde on a playne ageyne pat thyng and go toward it and froward it til pi sight beme passe by pe heght of pe zerde 
and of pat thyng. pan loke' howe mikil es bitwene pi fote and pe grounde of pat pyng in pe tyme of beholdynge. and to pat length set pe space fro pethen to pe erthe. pan multiply al pat by pe length of pe zerde. and pan departe al pat by pe space bitwene ye and pe zerde and perewith pe quantite fro pethen to pe erthe. and pat es pe heght. Also when you wilt mesure pe heght of any thing by two zerds, even corneldly joyned, take a zerde even to pe length of pi stature. and anoper zerde, tuo so longe als pat in pe myddel of pe lengere zerde, set pe schortere even corneldely pan pis instrument pus made layde by pe playne ground til by pe toppes of bothe pe zerdes you se pe toppe of the ping to be mesured, pan make pere a mark and set pereto pi stature. and pan set pe marke pere. and so heigh es pat thyng howe mekil length es bitwene pe grounde of pat thyng and pe latter mark. bot forgete noght pat perpendicle or equipendy, pat es to say, even hangere lolle by pe toppe of pe longer rodde to schewe when pin instrument es even vpright, and when it bagges Ensample, pe stature of pe matere be called $A B$, pe zerde doubling it $\mathrm{CD}$ pe zerde evene corneldy joyned to it $\mathrm{AE}$, and the foundement of pe pyng $\mathrm{F}$, pan I say pe height of the pyng es $\mathrm{BF}$, with pe quantite of $\mathrm{BC}$. When you standes by a walle of a castelle or toure, and you wolde mesure pe heght of it with outen defaute, make

1 MS. loloke. 
a quadrat or quarterd. pat es to say a table even foure square of wode or brasse of what quantite you wilt, and ay pe more it be. pe better it es. and loke it be over alle square. in pe manner of $A B C D$ and put a chippe of what length you wilt in pe cornelle $\mathrm{B}$ and anoper in pe cornelle $\mathrm{C}$ and pe pird in pe cornel $\mathrm{D}$ and loke pei be fast on pat quadrat pat evenly pei stande raysed vp. and pe side of pe quadrat bitwene A and B mote be persede reulefully. in whilk persyng put a chippe like be oper thre. bot it sale be moveable fro $A$ to $B$ and pis chippe sale hight $E$ and wite you that A es pe right cornel vpward. B pe left cornel vpward. C pe left cornel donward. D pe right cornel donward. When pe face of pe quadrat es torned toward ye. and pese chippes I calle eighen as in pe quadrant, pan loke even vp by $\mathrm{C}$ and $\mathrm{B}$ chippis or eighne to pe heyest of pe toure. So pat pe quadrat joyne to pe walle. and pat highest of pe toure sale hight $\mathrm{F}$ loke pe side $\mathrm{AB}$ be departed on 30 or 40 or howe fele you wilt. and in pe same manere departe pe side $\mathrm{AD}$. pan move pe chippe $\mathrm{E}$ hedire and pedire til you se pe hiest $F$ ageyne thurgh chippes $D, E$ noght chaunging pe raper place $\mathrm{BC}$ pan biholde where pe chippe $\mathrm{E}$ stondes bitwene $\mathrm{A}$ and $\mathrm{B}$ and loke howe mekil pat part es $\mathrm{EA}$ to $\mathrm{AD}$ and so mekil part es $D C$ to $C B F$ and howe ofte $E A$ es in $A B$ so ofte es $C D$ in $C B F$ forpi multiply $D A$ in $A B$ and pat comes pereof departe by $\mathrm{AE}$ and pat nonmbre howe ofte it be es pe heght of CBF and 
pat you have al the heght fro $\mathrm{F}$ to pe erthe. mesure pe length $A C$ to pe erth. whilk length set to pe heght CBF and pat comes is pe verey heght. If you wilt mesure pe heght of any thyng by a myrure. lay pe myrure in pe playne grounde, and go toward and froward til you se pe toppe of pat thing in pe mydel of pat myrure. pan multiply pe playne bitwene pe foundement of pat thyng to be mesured and pe myrure by pe space fro pethen to pe erthe. and pat comes pereof departe by be space bytwene pi fote and pe myroure and pe nonmbre howe ofte it be es pe heght of pat thyng. Also als fro pethen to pe erthe has it to pe space bytwene pi fote and pe myrure so pe heght of pat thyng has it to pe playne. Whilk es bitwene pe rote of pat thyng to be mesured and pe myrure and so ageyne.

Nowe we have taght to mesure the heght of a thynge whill es the first parte of oure tretis. We wil teche to mesure the playne. for that es the seconde parte.

When you wilt mesure pe length of any playne with pe quadrant stonde in one ende of pe playne and byholde pat oper by bothe holes. and holde pe cone. pat es to say pe cornelle of pe quadrant nere pin eigh. and pe compas toward pe playne to be mesured. pan when you sees pe oper ende of pat playne take pe nonmbre of pe poyntes of pe vmbre froward whilk be perpendicle kyttes. pan multeply 
pe distaunce. pat es to say pe space fro pethen to pe erthe by 12 and departe pat comes pereof by pe nonmbre of pe vmbre of pe poyntes froward raper had. and pe nonmbre howe ofte it be es pe quantite of pe length of pat playne. Parcas pe playne whose length you wolde mesure es noght evene nor even distondyng to pin orisont. pat es to say to pe ende of pin sight. bot pat playne es lift vp and croked. pan biholde pe crokidnes pereof by pe holynge. pat es to say pe eyghne of pe quadrant. whilk bus you schalt do. set vpright tuo zerdes of one length in pe endes of pe playne to be mesurede. pan biholde pe toppes of pise thynges by bothe pe eyghne of pe quadrant. pan loke howe fele poyntes pe perpendicle kyttes. and pat of pe vmbre froward. if parcas pe perpendicle falle vpon pe poyntes of pe vmbre toward. pan torne pem into pe poyntes of pe vmbre froward. pan kepe pise poyntes. Est se pe ende of pat playne by bothe pe eyghen of pe quadrant. and loke howe fele poyntes of pe vmbre froward pe perpendicle kyttes. pan set pese poyntes to pe poyntes raper kept. if you stonde in a lowere place aftere ban you did bifore. and if you stonde in an heighere. pan take away pe poyntes raper kept. pan do with pise poyntes as you did with pe poyntes in pe next Chapitere bifore in mesuryng of an evene playne. pat es to say multeply pe distaunce fro pethen to pe erthe by 12 and depart pat comes pereof by pe poyntes of pe vmbre froward. and pe nonmbre howe ofte it be es pe 
quantite of pe length of pat playne. When you wilt mesure pe playne of lande or water withouten pe quadrant. take pan tuo zerdes and rayse pat one even vp right on pe playne. and calle pe playne $\mathrm{BE}$ and pe zerde vp raysed $\mathrm{AB}$ in whilk zerde set evene corneldly anoper zerde even distonding to pe playne and pis zerde sale hight $C D$ pan beside pe zerde $\mathrm{vp}$ raised $\mathrm{AB}$ set pin eigh and biholde pe ende of pe playne to be mesurede. and mark by whilk place of pat oper zerde CD pi sight bem passes. and calle bat poynte $\mathrm{E}$ pan by pe quantite of pe seconde zerde CD multeply pe first zerde $\mathrm{AB}$ and departe pat comes pereof by pe quantite of $\mathrm{AC}$ and pan comes pe length of pe playne. When you wilt wite whilk es pe brede of a ryvere. kast a table vpon pe grounde nere pe ryvere. pan biholde pe ende of pat oper side pe ryver by a reulure vpon pe table. And drawe a lyne by pe reulure on pe table. Est se pe forsaide ende by pe same reulure in an oper place of pe table. and pere make anoper line. pan go in a playne place and lay a threde on pat one lyne. and anoper threde on pat oper lyne and continu pem even til pei come to gidere. and howe mykel distaunce pat es to say space es fro pe metyng of pe thredes to pe table so brode es pe ryvere. When you wilt mesure pe brede of a ryvere by a quadrat, make pi quadrat $\mathrm{ABCD}$ as it es saide bifore of mesuryng of heght by pe quadrant. pan set pe quadrat beside pe ryvere and loke by $\mathrm{CB}$ pe ende on pat opyer side pe ryvere. and calle pat 
ende $F$ and $B$ es pe ende on pis side pe ryvere. pan go fro $B$ poynte by an evene lyne with pis quadrat. and pat pe reulure of pat lyne be octhogonyely. pat es to say even corneldly bytwene $B$ and $F$ til yu se est pe ende $F$ by pe poyntes or chippes $\mathrm{D}, \mathrm{B}$ in pe quadrat. and calle $\mathrm{G}$ pe mark in pe place of pe seconde site. pat es to say stondynge pan howe mekil length es bitwene B and $G$ so mekil as pe brede bytwene $B$ and $F$. Also when you stondes by a ryvere and wille mesure pe brede of it. put pis quadrat vpon pe erche nere pe ryvere. and biholde by pe lyne CB pe ende on pat oper side pe ryvere whilk es called F. pan move $\mathbf{E}$ hedire and pidere til you se pe same ende $F$ by $D E$ noght changyng pe first place of $\mathrm{BC}$. pan biholde where $\mathrm{E}$ stondes bitwene $\mathrm{A}$ and $\mathrm{B}$ pan multiply $\mathrm{DA}$ into $\mathrm{AB}$ and departe pat comes pereof by $\mathrm{AE}$ and pe nonmbre pat comes howe oft it be es pe brede of pe ryvere whilk es BF. When you wilt mesure a playne by a mesure. pan rayse $\mathrm{vp}$ right on pe playne a rod of pe length fro pin eigh to pe erche. and calle pat rod $\mathrm{AB}$. on pat rod hange a litel myrure. and ay pe lesse pe better. and pe place on pe rod where pe myroure hanges calle $\mathrm{C}$ and pe playne to be mesurede sale hight $\mathrm{AD}$. pan stonde you vpon po playne bitwene pe myrure and pe ende of pe length of pe playne. and loke in pe myrure movyng toward and froward pe myrure til you se pe ende of pe playne in pe mydille of the myrure. pat place of pe playne where you stondes 
you sale calle it $\mathbf{E}$. pan multiply pe length of pi stondynge fro pe zerde by pe quantite bytwene pe myrure and pe playne. and departe pat comes pereof by pe distaunce of pe myrure fro pe hyere parte of pe rod. and pat nonmbre howe ofte it be es pe length of pat playne. as pus. multiply $\mathrm{AE}$ in $\mathrm{AC}$ and depart pat comes pereof by pe lyne CB. and pe nonmbre pat comes pereof es pe length of pe playne.

Nowe we have taght to mesure the playnes of ill erthly thyng whilk es the secunde parte of this tretyse. So we teche to mesure the depnes. for that es the thrid parte and laste of this bole.

When you wille mesure pe depnes of a welle. loke fro pat one side of pe welle to pe ende of pat oper syde in pe bothome of pe same welle with pe quadrant. and holde pe cornel of pe quadrant nere pine eigh. and pe circumferens toward pe welle and take hede what es pe nonmbre of pe poyntes of pe vmbre toward vpon whilk pe perpendicle falles. pan mesure pe diameter of pe pit or welle. pat es to say pe mouthes brede. and multiply pat by 12 and depart pat comes pereof by pe nonmbre of pe forsaide poyntes and howe ofte pat nonmbre be. it es pe depnes of pat pitte. Also for pe same. rayse vp a table on pe mouthe of pe welle. pan put vpon be table a reulure whereby biholde you pe ende on pe bothome pereof. pan make per a lyne by pat reulure. est put pe reulure in anoper place 
of pe table. and pan se by pat reulure pe forsaide ende. and pere make anoper lyne by pe reulure in pat table. pan lay pe table vpon pe playne grounde. and lay on pise tuo lynes tuo thredes even til pei mete. pan mesure pe distaunce bitwene be metyng of po thredes and pe table. and so depe es pe welle. Also for pe same.rayse even vp on pe mouthe of pe well swilk a quadrat as we spak of bifore. pan by CB loke pe ende in pe bothome of pe welle. and pat sale hight $\mathrm{F}$. pan move $\mathrm{E}$ toward and froward til by DE you se est $F$ noght chaungynge pe first place BC. pan biholde where $\mathrm{E}$ stondes bytwene $\mathrm{AB}$. pan multiply $\mathrm{DA}$ in $\mathrm{AB}$ and departe pat comes pereof by AE. and pat nonmbre howe oft it be es pe depnes of pe welle. whilk es BF.

Nowe oure tretis of geometri es thus endid. 


\section{AN ACCOUNT TABLE}

FOR THE

USE OF MERCHANTS.

FROM A MS. OF THE FOURTEENTH CENTURY.

Bib. Sloan. Mus. Brit. 213.

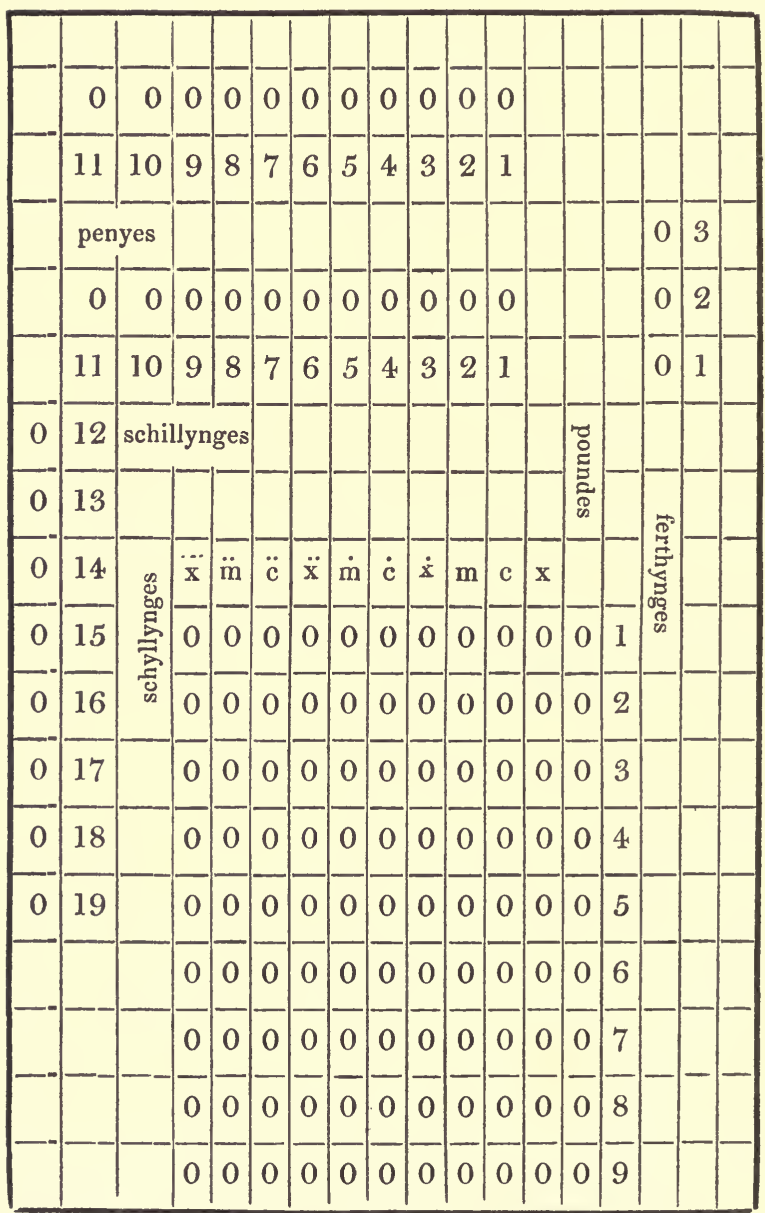

This es tabil marchaunte for alle manere acountes. 


\section{CARMEN DE ALGORISMO.}

$\mathrm{H}_{\star C}$ algorismus ars præsens dicitur ;2 in qua Talibus Indorum ${ }^{3}$ fruimur bis quinque figuris.

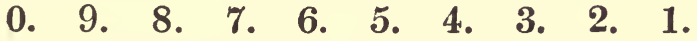

Primaque significat unum: duo vero secunda:

Tertia significat tria : sic procede sinistra

Donec ad extremam venias, quæ cifra vocatur;

Quæ nil significat; dat significare sequenti.

Quælibet illarum si primo limite ponas, Simpliciter se significat: si vero secundo,

2 “Hæc præsens ars dicitur algorismus ab Algore rege ejus inventore, vel dicitur ab algos quod est ars, et rodos quod est numerus; quæ est ars numerorum vel numerandi, ad quam artem bene sciendum inveniebantur apud Indos bis quinque (id est decem) figuræ." Comment. Thome de Novo-Mercatu. MS. Bib. Reg. Mus. Brit. 12 E. 1.

3 "Hæ necessariæ figuræ sunt Indorum characteros." MS. de numeratione. Bib. Sloan. Mus. Brit. 513, fol. 58. "Cum vidissem Yndos constituisse $1 \mathrm{x}$ literas in universo numero suo propter dispositionem suam quam posuerunt, volui patefacere de opere quod sit per eas aliquidque esset levius discentibus, si Deus voluerit. $\mathrm{Si}$ autem Indi hoc voluerunt et intentio illorum nihil novem literis $\mathrm{f}_{\text {uit, causa }}$ quæ mihi potuit. Deus direxit me ad hoc. Si vero alia dicam præter eam quam ego exposui, hoc fecerunt per hoc quod ego exposui, eadem tam certissime et absque ulla dubitatione poterit inveniri. Levitasque patebit aspicientibus et discentibus." MS. Bibl. Publ. Cant. 1869, Ii. vi. 5. 
Se decies: sursum procedas multiplicando. Post prædicta scias breviter quod tres numerorum Distinctæ species sunt; nam quidam digiti sunt; Articuli quidam; quidam quoque compositi sunt. Sunt digiti numeri qui semper infra decem sunt; Articuli decupli digitorum; compositi sunt Illi qui constant ex articulis digitisque. Ergo, proposito numero tibi scribere, primo Respicias quis sit numerus; quia si digitus sit, Una figura satis sibi; sed si compositus sit, Primo scribe loco digitum post articulum; atque Si sit articulus, in primo limite cifram, Articulum vero tu in limite scribe sequenti. Quolibet in numero, si par sit prima figura, Par erit et totum, quicquid sibi continuatur; Impar si fuerit, totum sibi fiet et impar. Septem ${ }^{4}$ sunt partes, non plures, istius artis ; Addere, subtrahere, duplareque dimidiare; Sextaque dividere est, sed quinta est multiplicare ; Radicem extrahere pars septima dicitur esse. Subtrahis aut addis a dextris vel mediabis; A leva dupla, divide, multiplicaque;

${ }^{4}$ En argorisme devon prendre

Vii especes

Adision subtracion

Doubloison mediacion Monteploie et division Et de radix enstracion A chez vii especes savoir Doit chascun en memoire avoir Letres qui figures sont dites Et qui excellens sont ecrites.

MS. Seld. Arch. B. 26. 
Extrahe radicem semper sub parte sinistra..$^{5}$ Addere si numero numerum vis, ordine tali Incipe; scribe duas primo series numerorum Primam sub prima recte ponendo figuram, Et sic de reliquis facias, si sint ibi plures. Inde duas adde primas hac conditione: Si digitus crescat ex additione primorum, Primo scribe loco digitum, quicumque sit ille; Sed si compositus, in limite scribe sequenti Articulum, primo digitum; quia sic jubet ordo. Articulus si sit, in primo limite cifram, Articulum vero reliquis inscribe figuris; Et per se scribas si nulla figura sequatur. Si tibi cifra superveniens occurrerit, illam Dele suppositam; post illic scribe figuram: Postea procedas reliquas addendo figuras. A numero numerum si sit tibi demere cura, Scribe figurarum series, ut in additione; Majori numero numerum suppone minorem, Sive pari numero supponatus numerus par. Postea si possis a prima demere primam, Scribas quod remanet, cifram si nil remanebit. Sed si non possis a prima demere primam; Procedens, unum de limite deme sequenti; Quod demptum pro denario reputabis ab illo, Subtrahe totalem numerum quem proposuisti. Quo facto, scribe super quicquid remanebit, Facque nonenarios de cifris, cum remeabis, Occurrant si forte cifræ, dum demeris unum; Postea procedas reliquas demendo figuras. 
An subtractio sit bene facta probare valebis, Quas subtraxisti primas addendo figuras. Nam, subtractio si bene sit, primas retinebis, Et subtractio facta tibi probat additionem. $\mathrm{Si}$ vis duplare numerum, sic incipe; solam Scribe figurarum seriem, quamcumque voles tu ; Postea procedas primam duplando figuram; Inde quod existit, scribas, ubi jusserit ordo, Juxta præcepta quæ dantur in additione. Nam si sit digitus, in primo limite scribe; Articulus si sit, in primo limite cifram, Articulum vero reliquis inscribe figuris; Vel per se scribas, si nulla figura sequatur: Compositus si sit, in limite scribe sequenti Articulum, primo digitum; quia sic jubet ordo: Et sic de reliquis facias, si sint ibi plures. Incipe sic, si vis aliquem numerum mediare: Scribe figurarum seriem solam, velut ante; Postea procedas medians, et prima figura Si par aut impar videas; quia si fuerit par, Dimidiabis eam, scribens quicquid remanebit; Impar si fuerit, unum demas mediare, Quod non præsumas, sed quod superest mediabis ; Inde supertactum, fac demptum quod notat unum; Si monos, dele; sit ibi cifra post nota supra. Postea procedas hac conditione secunda: Impar $^{6}$ si fuerit, hinc unum deme priori, Inscribens quinque, nam denos significabit Monos prædictam : si vero secunda sit una, Illa deleta, scribatur cifra; priori

6 i. e. figura secundo loco posita. 
Tradendo quinque pro denario mediato ;

Nec cifra scribatur, nisi deinde figura sequatur :

Postea procedas reliquas mediando figuras,

Ut supra docui, si sint tibi mille figuræ.

Si mediatio sit bene facta probare valebis,

Duplando numerum quem primo dimidiasti.

Si tu per numerum numerum vis multiplicare, Scribe duas, quascunque velis, series numerorum;

Ordo tum servetur, ut ultima multiplicandi Ponatur super anteriorem multiplicantis;

A leva reliquæ sunt scriptæ multiplicantis. In digitum cures digitum si ducere, major Per quantum distat a denis respice, debes Namque suo decuplo tocies delere minorem; Sicque tibi numerus veniens exinde patebit. Postea procedas postremam multiplicando, Recte multiplicans per cunctas inferiores, Conditione tamen tali ; quod multiplicantem Scribas in capite, quicquid processerit inde; Sed postquam fuerit hæc multiplicata, figuræ Anteriorentur seriei multiplicantis ; Et sic multiplica, velut istam multiplicasti, Quæ sequitur numerum scriptum quibusque figuris. Sed cum multiplicas, primo sic est operandum, Si dabit articulum tibi multiplicatio solum; Proposita cifra, summam transferre memento. Sin autem digitus excreverit articulusve, Articulus supraposito digito salit ultra; Si digitus autem, ponas ipsum super ipsam, Subdita multiplicans hanc quæ super incidit illi Delebit penitus, et scribens quod venit inde; 
Sed cum multiplicat aliam positam super ipsam, Adjunges numerum quem probet ductus earum; Si supraposita cifra debet multiplicare, Prorsus eam delet, scribi quod loco cifra debet, Sed cifra multiplicans aliam posita super ipsam, Sitque locus supra vacuis super hanc cifra fiet; Si supra fuerit cifra semper pretereunda est ; Si dubites, an sit bene multiplicatio facta, Divide totalem numerum per multiplicantem, Et reddet numerum emergens inde priorem. $\mathrm{Si}$ vis dividere numerum, sic incipe primo; Scribe duas, quascunque velis, series numerorum; Majori numero numerum suppone minorem, Nam docet ut major teneat bis terve minorem; Et sub supprima supprimam pone figuram, Sic reliquis reliquas a dextra parte locabis ; Postea de prima primam sub parte sinistra Subtrahe, si possis, quocies potes adminus illud, Scribens quod remanet sub tali conditione; Ut toties demas demendas a remanente, Quæ serie recte ponuntur in inferiori, Unica si, tum sit ibi decet hac operari ; Sed si non possis a prima demere primam, Procedas, et eam numero suppone sequenti; Hanc uno retrahendo gradu comites retrahantur, Et, quoties poteris, ab eadem deme priorem, Ut toties demas demendas a remanente, Nec plusquam novies aliquem tibi demere debes, Nascitur huic numerus quociens supraque sequentem Hunc primo scribas, retrahens exinde figuras, Dum fuerit major suppositus inferiori, 
Et rursus fiat divisio more priori ;

Et numerum quotiens supra scribas pereunti, Si fiat saltus retrahendo cifra locetur,

Et pereat numero quotiens, proponas eidem Cifram in numerum pereat vis, dum locus illic Restat, et expletus divisio non valet ultra: Dum fuerit numerus minor inferiore seorsum Illum servabis; hunc multiplicando probabis, Si bene fuisti, divisor multiplicetur

Per numerum quotiens; cum multiplicaveris, adde Totali summæ, quod servatum fuit ante, Redditurque tibi numerus quem proposuisti ; Et si nil remanet, hunc multiplicatio reddet. Cum ducis numerum per se, qui pervenit inde Sit tibi quadratus, ductus radix erit ejus, Nec numeros omnes quadratos dicere debes, Est autem omnis numerus radix alicujus. Cum voles numeri radicem quærere, scribi Debet; deinde notes si sit locus ultimus impar, Estque figura loco talis scribenda sub illo, Quæ, per se ducta, numerum tibi destruit illum, Vel quantum poteris ex huic delebis eadem; Et retrahendo duples retrahens duplando sub illa Quæ primo sequitur, duplicatur per duplacatam, Post per se minuens sub ea saliendo.

Post his propones digitum, qui, more priori Per precedentes post per se multiplicatus, Destruit in quantum poterit numerum remanentem, Et sic procedas retrahens duplando figuram, Reponendo novam donec totum peragatur, Subdupla propriis servare docetque duplatis; 
Si det compositum numerum duplacio, debet Inscribi digitus a dextra parte propinqua, Articulusque loco quo non cedebat duplicando ; Si dabit articulum, sit cifra loco pereunte Articulusque locum tenet unum, duplanda recessit; Si donet digitum, sub prima pone sequente, Si supraposita fuerit duplicata figura Major proponi debet tantum modo cifra, Has retrahens solito propones more figurarum, Usque sub extrema ita fac retrahendo figuras, Si totum debes numerum quem proposuisti, Quadratus fuerit de dupla quem duplicasti, Sicque tibi radix illius certa patebit, Si de duplatis sit juncta supprima figura; Si radicem per se multiplices habeasque Propositum primo, bene te fuisse probasti ; Non est quadratus, si quis restat, sed habuentur Radix quadrati qui stat major sub eodem; Vel quicquid remanet tabula servare memento; Hoc casu radix per se quoque multiplicetur, Et sic quadratus sub primo major habetur, Huic addas remanens, et prius debes habere; Si locus extremus fuerit par, scribe figuram Sub pereunte loco per quam debes operari, Quæ quantum poterit supprimas destruat ambas, Vel penitus legem teneas operando priorem, Si suppositum digitus in fine repertus, Omnino delet illic scribi cifra debet, A leva si qua sit ei sociata figura; Si cifræ remanent in fine pares decet harum Radices, numero mediam propone partem, 
Tali quesita radix patebit arte reperta.

Per numerum recte si nosti multiplicare Ejus quadratum, numerus qui pervenit inde Dicetur cubicus; primus erit radix ejus; Nec numeros omnes cubicatos dicere debes, Est autem omnis numerus radix alicujus ; Si cures cubici radicem quærere, primo Inscriptum numerum distinguere per loca debes ; Quæ tibi mille notant a mille notante supprima Junctum, summes operandi parte sinistra, Illic et scribas digitum, qui multiplicatus In semet cubicæ suprapositum sibi perdat, Et si quid fuerit adjunctum parte sinistra Si non omnino quantum poteris inveniendo, Hunc triplans retrahe saltem, faciendo sub illo Quod manet a digito deleto; terna figura Sibi propones quæ sub triplo asocietur, Et cum subtriplo per eam tripla multiplicatur ; Hinc per eam solam productum multiplicabis, Postea totalem numerum, qui pervenit inde A suprapositis respectu tolle triplatæ Addita supprimo cubicæ tunc multiplicetur, Respectu cujus, numerus qui progredietur Ex cubito ductu suprapositis adimetur; Tunc ipsam dele triples saltum faciendo, Semper sub terna, retrahens alias triplicatas Ex hinc triplatis aliam propone figuram, Quæ per triplatas ducatur more priori ; Primo sub triplis sibi junctis, postea per se, In numerum ducta, productum de triplicatis: Utque prius dixi numerus qui prevenit inde 
A suprapositis has respiciendo trahatur, Huic cubicæ junctum supprimo multiplicabis, Respectuque sui, removebis de remanente, Et sic procedas retrahendo triplando figuras. Et proponendo nonam, donec totum peragatur, Subtripla sub propriis servare decet triplicatis; Si nil in fine remanet, numerus datus ante Est cubicus; cubicam radicem sub tripla probent, Cum digito juncto quem sub primo posuisti, Huic cubicæ ducta, numerum reddant tibi primum. Si quid erit remanens non est cubicus, sed habetur Major sub primo qui stat radix cubicati, Servari debet quicquid radice remansit, Extracto numero, decet hoc addi cubicato. Quo facto, nnmerus reddi debet tibi primus. Nam debes per se radicem multiplicare Ex hinc in numerum duces, quod pervenit inde Sub primo cubicus major sic invenietur; Illi jungatur remanens, et primus habetur, Si per triplatum numerum nequeas operari; Cifram propones, nil vero per hanc operari Sed retrahens illam cum saltu deinde triplatam, Propones illi digitum sub lege priori, Cumque cifram retrahes saliendo, non triplicabis, Namque nihil cifræ triplacio dicitur esse; Aut tu cum cifram pertraxeris autem triplicatam, Huic cum subtriplo semper servare memento: Si det compositum, digiti triplacio debet Illius inscribi, digitus saliendo super ipsam; Quæ manet a digito deleto, terna figura; Articulus jungitur cum triplata pereunte, 
Sed facit hunc scribi per se triplacio prima, Quæ si det digitum per se facit scribi illum; Consumpto numero, si solæ fuit tibi cifræ Triplatæ, propone cifram saltum faciendo, Cumque cifram retrahe triplatam, scribendo figuram, Propones cifræ, sic procedens operare, Si tres vel duo series sint, pone sub una, A dextris digitum servando prius documentum. 


\section{PREFATIO}

\section{DANIELIS DE MERLAI}

AD LIBRUM

DE NATURIS SUPERIORUM ET INFERIORUM.

Bib. Arundel. Mus. Brit. 377 .

Philosophia magistri Danielis de Merlai ad Johannem Norwicensem episcopum.

Cum dudum ab Anglia me causa studii excepissem et Parisius aliquandiu moram fecissem, videbam quosdam bestiales in scholiis gravi auctoritate sedes occupare, habentes coram se scamna duo vel tria et descriptos codices importabiles aureis literis Ulpiani traditiones representantes: necnon et tenentes stilos plumbeos in manibus, cum quibus asteriscos et obelos in libris suis quadam reverentia depingebant: qui dum propter inscientiam suam locum statue tenerent, tamen volebant sola taciturnitate videri sapientes: sed tales cum aliquid dicere conabantur infantissimos ripperiebam. Cum hoc, inquam, in hunc modum se habere Deprehenderem, ne et ego simile damnum incurrerem, artes que scripturas illuminant 
non in transitu salutandas vel sub compendio pretereundas mecum sollicita deliberatione tractabam. Sed quoniam doctrina Arabum, que in quadruvio fere tota existit, maxime his diebus apud Toletum celebratur, illuc ut sapientiores mundi philosophos audirem, festinantur properavi. Vocatus vero tandem ab amicis et invitatus ut ab Hyspania redirem, cum pretiosa multitudine librorum in Angliam veni. Cumque nunciatum esset mihi quod in partibus illis discipline liberales silentium haberent, et pro Ticio et Seio penitus Aristotiles et Plato oblivioni darentur, vehementer indolui, et tamen ne ego solus inter Romanos Græcus remanerem, ubi hujusmodi studium florere didiceram, iter arripui. Sed in ipso itinere obviam honorem Dominum meum et principem spiritualem Johannem Norwicensem episcopum qui me honorifice ut eum decebat recipiens; valde meo congratulabatur adventui. 


\section{PROPOSA L S}

FOR SOME

\section{INVENTIONS IN THE MECHANICAL ARTS.}

A Note of sundry sorts of Engynes. 1583.

1. First a carriedge with his properties to carry or drawe fyve hundreth weight with one mans strength.

2. An ingen of wonderfull strength to pull downe parcullices or irone gatts.

3. A chaine of yron non licke it in strength of his bidgnes.

4. A paire of gripes to the same chaing belonging of strange fashone.

5. A gine to hoyste or pull vp earth to make rampiors.

6. A scaffolde to be removed.

7. A device to remove any burden of 10 tonne weight without horse or beast.

8. An ingen to lanch shippes.

9. A float to pase men over waters. 
10. A bridg to be carried for passing an army of men ordenaunce and such licke carriges over any ryvers, \&c.

11. A myll to grine by water winde or men for forte castell or towne of warr.

12. A crane to hoyst vp $\mathbf{1 0}$ or $\mathbf{2 0}$ tonne weight.

13. A gynne to hoyst vp any cannon and laie him in his carriage by one man onley.

14. An ingen for clensing or taking away of any shelves or shallow places in the river of Tems or any such river the same device maie serve for clensing of diches about citties or towns pondes or any such licke standing waters.

15. A water myll to rune longer then before tyme.

16. A winde myll and not to turne the howse about.

17. To make water workes for fountains cunditts and suche licke.

18. To make pipes of lead 6 or 7 foot long without sauder.

19. To make a boat to goe fast one the water without ower or saile. ${ }^{7}$

7 This was a favourite project about this time. In a few "speciall breife remembrances" of some "pleasante serviceable and rare inventions as I have by longe studie and chargeable practice founde out," addressed to Queen Elizabeth by Ralphe Rabbard, I find one headed "The rarest engyne that ever was invented for sea service;" and this is described as follows :"A vessell in manner of a Tally or Talliote to passe upon the seas and ryvers without oars or sayle against wynde and tyde, swifter than any that ever hath bynue seene, of wonderfull 
88 INVENTIONS IN THE MECHANICAL ARTS.

20. To preserve a boat from drowning and the people that be therein.

effect bothe for intelligence and many other admirable exploytes almost beyonde the expectation of man :" MS. Lansd. 121. Now see Bourne's Inventions or Devises, a book deserving the particular attention of all those who are interested in the history of mechanical inventions. Edmund Jentill, in 1594, proposed a "device wonderfull strange," similar to the above : it was one of the inventions which he offered to discover to Lord Burghley, on his release from prison, for counterfeiting foreign coin :-MS. Lansd. 77 and 113. 


\section{THE PREFACE}

\section{A CALENDAR OR ALMANAC}

FOR THE YEAR 1430.

MS. Harl. 937.

My soverayne maistres. certen evydens have done me to vnderstonde zour abylyte to lerne scyens partyculere, and als wele consyder I zour desyre in specyal to lerne a certen conclusyons of pe new kalender. I say a certen conclusyons for pys cawse for sum of paim profundely to be expressyd or lerned for defawte of termes convenyent in ower moder langage beyn to stronge to a tendyr wytte to comprehende pat is not elevate be processe and cowrse of scoles. perefor als myche as pe grete phylosophyr sayth he wrappyth hym in hys frende pat condescendyth to pe ryztfull prayer of hys frende .... me and mor mevyth me syth I .... bondene to make satisfactyon to zour desire prayng ever dyscrete persone pat pis redyth or heryth to have my rude endytyng excusyd and 
my superfluyte of wordes for two cawses. pe furste cawse for so curyos and harde sentens in obscure termes is full tedyos to syth a tender wytte to cousayne. pe secunde cawse is for sothely me semythe better to wryte and twyse teche one gode sentens pen ones forgoten. levyng perfore all vayn preambles of superfluyte pat papyr ful. fyllyzte with owtyn fruyte pis lesone I zyfe zow fyrste pat in zour zerus beyn xii moneth. January February March Aprile May June July Auguste Septembre Octobre Novembre Decembre. And ccc and sexty days and 5 and sex odde howres qwyche odde howres gedyrd togeder 4 zerus makyth 24, howres pat is a day naturale so pat in pis zere pat is clepyt lyp zere beyng ccc and sexty and sex days. In everych zere we vse a new letter pat Sonday gothe by. In pe lyp zere we occupy twene pe furste servyth fro new zerus day to seynt mathye day. pe secunde tellyth us owre soneday pe remnande of pe zere.

zour pryme schal be to zow a specyal doctour of dyverse conclusyons querfore in latyn he is clepyt pe golden nownbur and begynnyzt at one and rennyth to xix and turnyth azayn to one, and so in case pat one were pryme pis zere next zere schulde 2 be pryme and pe 3 zere 3 . so rennyng zere be zere to xix and azayn to one and so abowte with owten ende. In pe fyrst table of zowre kalendere by pe reede letters in pe firste lyne joyned to pe blake letters in pe secunde lyne schal ze knowe pe lyp zere qwen it fallyth. In 
pe 3 lyne beyn wryten primes frome one to xix and turnyth azayn. Seche pen zour prime of pe zere pat ze be in jonyd to pe domynycale letter of pe same zere and pen may ze se by pe rede letters in pe fyrst lyne qwenus it be lyp zere, or how nere ze be, pis ensample. I zyffe zow pe zere of owre lorde a.mccccxxx in qwych zere pis kalendere to zow was wryten. Went prime by 6 and zowre letter domynycale was A qwyche beyn jonyd and wryten to geder in pe hede and pe begynnyng of pis sayd table. pen behalde how pe next zere folowyng schal 7 be prime and $G$ domynycale. And pe next zere after schal 8 be prime and be lyp zere as ze may se by pe reede letter $\mathrm{F}$ jonyd to pe blak letter $\mathrm{E}$ so pat in pis lyp zere schal $\mathrm{F}$ be domynycale letter fro be Circumscycyon pat is clepyd newzerus day vnto seynt Mathye day. and pen schal $\mathrm{E}$ be zour sonday letter to pe zerus ynde as I sayd beforne. pis doctryne kepe purghe alle pe forsayd table. Amonge pe blak letters in pe same lyne beyn wryten reede letters qwyche teches pe indyccyon pat is a terme ful necessary to paim pat lyste knaw pe verray and certene date of pe Pope bulles and of pe olde Imperyale wrytynge of Rome. zyf it lyke zow to wytte in qwat Jndyccyon ze be in Take zour prime and zour domynycale letter of pe same zere pat ze beyn in qwyche letter in case pat it be rede calle pat pe first Jndyccyon and pe next letter pe secunde jndiccion and so rennyng vnto $\mathrm{xv}$ and zen azayn to one at pe 
next reede letter. zif it be a blake letter pat zour prime fallyth one cownte fro pe next goyng beforus and so mony is pe jndiccyon pat ze seche forzete not pis lesone.

A table pat next folowyzt is callyd pe table of pe 5 festes moveyabylle pat is to say qwen septuagesime commeyzt in pat is pe sonday before lentyn qwen Allia is closyd vp. Also pis table telly ${ }^{t}$ qwen lentyn fallyth qwen Eysterday. qwen pe Rogacyons and qwen qwytesoneday. It techy zt also how mony weykes be fro Crystemesday to lentyn how mony wekes and days fro qwytesonday to mydsommerday And how mony fro Whytesonday to pe advente on pis maner. Tak pe prime of pe zere pat ze be in. in pe fyrste lyne wryten with reede. and pe domynycale letter next folowyng in pe secunde lyne. and folowe stryght forthe in to pe lyne of pat thynge wryten in pe heyde pat ze desyre. and by pe nownbur pat ze fynde schalle ze knaw pat ze desyre. Vnderstonde wele pis ensample. Aftyr crystynmesse pe zere of owre lorde a.m.cccc.xxx. I was aferde of lentyn and lokyd in my kalender for septuagesime and lentyn how nere pai were and soghte my prime in pe fyrste lyne pat happynd to be 7 pe same tyme. and toke my domynycale letter pat was $G$ next following. po turnyd I forth fro pis $G$ streght in to nexte lyne pat haythe Septuagesime writyn in pe hede and I fonde 28 pere wryten pereby demyd I pat septuagesime sonday schal falle ze 28 day 
of pe moneyth of Januare wrytyn in pe hede. po loked I forthermore in pe next lyne that hayth lentyn wryten in pe hede and pere I fonde $\mathbf{1 8}$ wryten and pereby I demyd pat first sonneday of lentyn schulde be on pe 18 day of pe moneyth of February nexte wrytyn above zyt I loked forthermore in pe next lyne for Esterday and fonde pere 1 wryten and pen wyste I pat Esterday schulde be on pe firste day of pe moneythe of Aprile wrytyn next above. and yow take ensample as I have do and loke ze kepe pe same thurghe alle pe table. 


\title{
JOHANNIS NORFOLK
}

\section{IN ARTEM PROGRESSIONIS SUMMULA.}

\author{
MS. Harl. 3742.
}

In artem progressionis continue et discontinue secundum magistrum Johannem Norefolk incipit summula.

Non invenientes sed doctrinam tradita inde numerorum progressione ab Algore rege quondam Castellie suo in Algorismo de integris perficere curantes. occultas aliorum tradiciones si que fuerint penitus omittentes dummoda tales nostra assidua percunctacione non obstante re maxima nobis miranda ante nostram edicionem in nostras manus visuras nos nusquam recepisse fatemur testimonium tamen fide dignorum nostrorum amicorum nobis possibilitatem operis concludebat eo quod tales regulas utilem artem progressionis concernentes ante nostra tempora fuisse editas testabantur. Oportunum igitur apud nos indicavimus cum ars tam preciosa arithmeticeque sciencie prefulgida margarita conspectibus hominum se non presentabat sed quorundam forte inpericia incarcerata atque porcis oblata sciolos 
latebat circa possibilitatem operis novarumque regularum edicionem divino auxilio primitus invocato petitisque auctoritatibus et favoribus eorum quibus incumbit hujusmodi summulas corrigere operas exiles soleritur impendere et eas sic collectas nostro calamo rudique stilo descriptas. Primo ad honorem Dei beatissime virginis Marie et omnium suorum sanctorum ac ad profectum animarum omnium fidelium defunctorum quarum collegio Oxonie primus vicecustos exciteramus et ad ceteras hujusmodi scienciam diligentes plenius promulgare curavimus. Reverendam ergo tuam benevòlenciam quiscunque es o carissime has nostras regulas exiles exiliterque collectas placito vultu bonoque animo ut acceptare digneris benigne rogamus. Est namque opus harum regularum omnium numerorum proportionalitate aliqua comperatorum sive plures paucioresve fuerunt ut in his exemplis. 1. 2. 4. 8. 16. 32. vel sic. 5. 6. 7. 8. vel sic. 4. 8. 12. 16. vel sic. 1.2. 3. 4. 5. 6. et sic ad quotitatem unitatum sive percussionum horologii quas sonat horologium ad 12 horas vel ad quartem partem diei naturalis et similibus quid resultans fuerit levi arificio explicare. Fiat obsecramus legitimum kalendare ergo in anima tua o lector honorande hoc scriptum exiguum magna tamen solertia et industria compilatum nec desit tibi spes enarrandi quid ex predictis numeris resultat et omnibus consimilibus proportionalitate aliqua comperatis cum regule satis sufficienter 
sunt tradite et nomen auctoris publice prefato est monstratum preambulo. Sic ergo karissime incipe et mente tua recollige tria documenta generalia que tractatus presentis processimi plenissime facilitabunt. Primum documentum est quod scias quid progressio sit et quod sectionem patitur in continuam et discontinuam prout posterius apercius clarescet. Secundum documentum est ut bene consideres quod omnium numerorum ordinate se in progressione habencium aliqua proportionalitas reperta nec quid ex talibus artificiose poterit certificari propter infinite variabilitatis talem. Tercium est quod non deficiat tibi spes perveniendi in finem premissum per hanc artem facillimam cum de omnibus numeris proportionalitate geometrica ordinatis ac de quibusdam arithmetica proportionalitate magis famose reperibilibus dantur regule sequentes solum omittentes numeros inusitatos arithmetica tamen proportionalitate constitutos ac omnes numeros musica proportionalitate collectos tum facilius sit enarrare qui ex talibus numeris resultat quam hujusmodi numeros artificiose reperire et componere et hec tria documenta nota diligentissime. Specificantes modo predicta tria documenta generalia dicamus primo quod progressio est numerorum diversorum ordinata collectio et dicitur ordinata pro tanto quod si aliqua collectione numerus minor sequatur majorem ut hic. 12 65. 413. ibi non est ratio progressio judicanda quamvis enim metaphorica progressio nuncupanda 
est omnis numerorum collectio a minore incipiendo terminando in majorem numerum ipsa tamen proprie dicitur progressio cum numeri quadam proportionalitate colliguntur istud namque evidentissimum est cum apud omnes maxime indicatur progressionem naturalem esse incipiendo computare ab unitate ascendendo ad alios numeros naturali ordine succedentes et ibi aliqua proportionalitas inter terminos reperta est et que postea apparebit. Progressio sic proprie sumpta dividitur in continuam et discontinuam progressio continua est numerorum diversorum ordinata collectio nullo numero alium superexcrescente nisi sola unitate et ista potest indrunter contingere vel incipiendo ab unitate vel ultra unitatem ut sic. 1. 2. 3. 4.5. vel sic. 3. 4.5. 6. et cætera. Progressio vero discontinua est numerorum diversorum ordinata collectio uno alio supraexcrescente plusquam unitate servata tamen ut prius in progressione continua proportionalitate geometrica et hoc indrunter incipiendo ab unitate vel altro numero quocunque ut hic. 1. 4. 7. 10. 13. et cætera. vel sic. 5. 7.9. 11.13.15. et cætera. Et quia progressio proprie dicta ut dictum est constat ex numeris geometrica proportionalitate covintis ne tractatus iste necessariis videatur deficere superfluisve habundare quorum utrumque collectoris impericie ascribendum esset videndum est de proportionalitate quid sit et ejus speciebus quæ etiam species ejus. ad hanc artem magis pertinet que vero abji- 
cienda. Est namque proportionalitas duarum proportionum aut plurimum in simul comperatorum habitudo hujus autem tres sunt species scilicet geometrica arithmetica arismonica sive musica proportionalitas geometrica est quando sunt tres termini aut plures et equales est excessus secundi ad primum sicut tertii ad secundum et quarti ad tercium et cætera si tanti fuerint ut hic. 1. 2. 3. 4. 5.6. vel sic. 2. 4.6.8. vel sic. 2. 7. 12. 17. 22. et cætera. Proportionalitas vero arithmetica est quando sunt tres ter mini vel plures et equalis est proportio inter primum et secundum et secundum ad tertium et tercium ad quartum ut hic. 1.2. 4.8. 16. vel sic. 1. 3. 9. 27. et cætera. Sed proporcionalitas musica sive arsmonica est quando sunt tres termini insimul proporcionalitati et equalis est proporcio tercium ad primum sicut est proporcio excessus tercii ad secundum ad excessum secundi ad primum ut hic. 3. 4. 6. vel sic. 6. 8. 12. vel sic. 12. 16. 24. hiis sic brevissime recitatis per nos dicamus quod in omnibus numeris proporcionalitate geometrica proporcionalitatis hec ars habet locum sive plures fuerint sic pauciores eciam in numeris famosioribus arithmetica proporcionalitate comperatis ut in numeris proporcionalitate duplica collectis omittentes alias species ejusdem proporcionalitatis sicut omittimus omnes species arsmonica proporcionalitate integritas ob id quod superius docetur documento tertio. Hiis sic specificatis inducamus primam 
regulam primo de numero geometrica proporcionalitate adunatis et ubi progressio continua est que hec est. Numero locorum secundum progressionem continuam exeunte sub numero pari per minus medium multiplicetur numerus locorum et habetur quod queritur hæc namque regula generalis est ut ostendent exempla posita in prima tabula in fine tractatus hujus et quamvis hæc regula viris maturis aliqualiter arithmetice sciencie noticia inbutis satis lucida est ut tamen juvenes et minus provecti per eam sapiant sic eam delucidamus ut ejus aliarumque regularum recitandarum noticie perfectus habeantur primo notanda sunt quid nominis horum quinque terminorum scilicet numerus locorum vel loca numerorum numerus par numerus impar majus medium minus medium eiis quinque terris nostro more declaratis facilime perquiritur sensus regule precedentis ac cujusque quatuor regularum sequencium. Sic vero incipientes dicamus quod non probabile aliquem pro eadem morula sive eodem .... plures numeros recitare et sic numerum primo recitatum dicimus esse in primo loco et secundo recitatum numerum dicimus esse in secundo loco et sic de aliis quibuscumque recitandis conformiter sicut si numeri diversi scribi debeant oportet quod variis locis scribantur et de eiis idem indicare quoad loca quare citissime cognoscitur numerus locorum secundum numeracionem numerorum enumeratorum. De secundo et tercio ternimis in simul licet annotare quia 
cognito quid sit numerus par tanquam suum privatum cognoscitur numerus inpar qui aliam cognicionem non habet quam per suum positivum ut docet aristolus. Est autem numerus par ut notat Boycius in sua arithmetica et est sua prima definitio illius quilibet numerus qui potest in duo equalia nullo medio intercedente dividi ab hac namque condicione deficit numerus impar ut constat quia quamvis quinarius dividi potest in duos binarios etiam in duo equalia tamen aliqua unitas integrans quinarium intercidit cum duo et tria faciunt quinque. Ceterum restat declarare quid minus medium quidve majus medium sit promissum ut impleatur pro quorum noticia est primo animadvertendum quid sit medium. Est namque medium quod equaliter distat ab extremis et sicut facilime ymaginatur medium ubi loca numerorum numerantur numero impari ut hic 1. 2. 3. 4. 5. 3. est medium vel sic ubi loca numerorum numerantur a numero pari saltem ultra binarium inveniendi sunt duo tales numeri quorum minor numerus mius medium dicitur et major numerus majus medium nuncupatur ut hic. 2. 3. 4. 5. numerus locorum est quatuor minus medium. 3. majus medium. 4. aut sic. 5. 8. 11. 14. 4. est numerus locorum ut prius minus medium est. 8. majus medium est. 11. hiis sic cognitis evidens est prima regula prius recitata de progressione continua et sequitur secunda regula de progressione continua eadem facilitate que hec est. Numero locorum secundum pro- 
IN ARTEM PROGRESSIONIS SUMMULA. $10 \mathrm{I}$

gressionem continuam existente sub numero impari per medium multiplicetur numerus locorum et habetur quod queritur sine aliqua subtractione vel additione et hec regula certissima est perfectus a nobis jam duabus regulis ad progressionem continuam pertinentibus succedunt. 3. regule spectantes ad progressionem discontinuam et quia in tali progressione minor erat difficultas nobis certitudinem regularum utilium invenire ut tamen posteri nostri eas regulas citissime cognoscant quas nostris magnis laboribus a diu percuntavimus licet ipse aliquibus obscuris terminis a nobis primo dentur declarationibus tamen nostris levissime conceptis quilibet mediocri ingenii capacitate fultus ipsas poterit facilime experiri et est prima regula talis. In progressione discontinua numero locorum exeunte sub numero pari et si eorum numerorum excessus nominatus fuerit a numero impari per majus medium intelligibile inter numeros mediales multiplicetur numerus locorum et subtrahatur medietas numeri locorum et habetur quod queritur hanc autem regulam assumpto hoc exemplo. 5. 10. 15. 20. sic delucidamus nam in exemplo dato numerorum loca esse sub numero pari nullius ambigit et unumquemque numerum excedere suum numerum in medietate precedentem per 5. 3. qui est numerus imper nulli dubium est tunc constat quod inter duos numeros mediales qui sunt 10. et 15. quatuor numeros ordine naturali intelligi posse videlicet 11. 12. 13. 14 . 
eorumque numerorum subintellectorum majus medium esse 13. hic vero numerus 13. multiplicandus est per numerum locorum scilicet 4. et subtrahatur 2. qui est medietas numeri locorum et patet summa ideo vero dicitur 13 . medium intelligibile quia non expresse inter numeros exemplo positos invenitur sed quadam solertia per intellectus indagacionem experitur ac eciam quod majus medium sit consimiliter indicatur. Hiis sic declaratis sequitur secunda regula que hec est. Si progressione discontinua numerus locorum fuerit par eorumque numerorum excessu exeunte sub numero pari per medium intelligibilem inter numeros mediales multiplicetur numerus locorum et habetur summa quesita hanc autem regulam duobus exemplis declaramus sic primum exemplum. 2. 4. 6. 8. in quo exemplo medium intelligibile est 5. qui ductus in numerum locorum exurgunt 20 ut evidet qui est summa totalis. Exemplum secundum prefate regule in quo exemplo numerus excessus est 4. medium vero intelligibilem 11. cum inter duos numeros mediales scilicet 9 . et 13 . ordine naturali intercipiuntur hii tres numeri scilicet 10.11. 12. aut intelligi possunt quorum medium est 11 . ut dictum est per quod multiplicetur numerus locorum et habetur numerus ex omnibus resultans. Ultima regula secundum genus proporcionalitatis geometrice et habita in ordine est hec progressione discontinua numero locorum ex- 
eunte sub numero impari per medium multiplicetur numerus locorum et habetur quod queritur exemplum 6. 8. 10. per 8. multiplicetur numerus locorum qui est tercia et exurgunt. 24. Et quia prius promissum est regulas fieri de quibusdam numeris arithmetica proporcionalitate comparatis hanc solam regulam disposuimus pro numeris magis famosis et sunt illi numeri qui proporcione dupla inter se comperantur ut hic 1.2.4.8.16.32. et cetera et est regula talis. Si plures numeri proporcionalitate arithmetica comperati ubi posterior suum inmediate priorem proporcione dupla excedit insimul comperentur dupletur ultimus et a resultante subtrahatur primus et habetur quod queritur evidet hec regula in exemplo posito nam dupatur 32. resultant 64. a quibus subtrahatur unitas que est primus numerus et resultant 63 . et hec regula generalis est in omnibus talibus sive ab unitate incipiatur sive non sive vero loca numerorum paria fuerint sive non de aliis autem numeris secundum hoc genus proporcionalitatis dicimus nunc ut dictum est prius documento tertio. et sic perfectus est iste tractatus brevissimus in collegio animarum Oxonie anno domini millesimo quadringentesimo quadragesimo quinto quod Norfolk scriptor ac compilator hujus tractatus.

\section{Explicit.}

Nil amplius restat ad perfeccionem hujus summule colligere et scribere quam quod anteadictum 
est sed solum regulas prescriptas ad facilitatem prospicere volencium recolligere cum tabulis exemplarium ac consulere quod lectores ejusdem perfecte sint in arte multiplicationis per intellectum ideo sequitur tabula subscripta et deo gratias.

\section{Prima regula.}

Numero locorum secundum progressionem continuam exeunte sub numero pari per minus medium multiplicetur numerus locorum et addatur medietas numeri locorum et habetur quod queritur.

Exemplum prime regule.

1.2 .3 .4 .5 .6 .7 .8 .9 .10 .11 .12 .

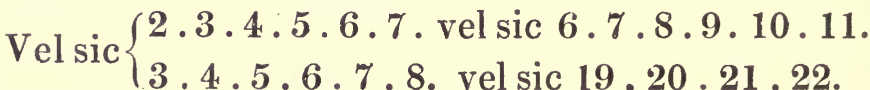

\section{Secunda regula.}

Numero locorum secundum progressionem continuam exeunte sub numero impari per medium multiplicetur numerus locorum et habetur quod queritur sine aliqua subtraccione vel addicione.

Exemplum secunde regule.

1 . 2.3 .4 .5. vel sic 5 .6.7.8 .9 . 10.11. vel sic $12 \cdot 13 \cdot 14 \cdot 15 \cdot 16$.

vel sic $21.22 .23 .24 \cdot 25.26 .27$. 


\section{Tercia regula.}

In progressione discontinua numero locorum exeunte sub numero pari et si eorum numerorum excessus nominatus fuerit a numero impari per majus medium intelligibilem inter numeros mediales multiplicetur numerus locorum et subtrahatur medietas numeri locorum et habetur quod queritur.

Exemplum tercie regule.

$$
\begin{aligned}
& .5 .10 .15 .20 .25 .30 . \text { vel sic } 2.5 .8 .11 \text {. } \\
& \text { vel sic } 3.10 .17 .24 .31 .38 \text {. } \\
& \text { vel sic } 3.6 .9 .12 .
\end{aligned}
$$

\section{Quarta regula.}

Numerus locorum si progressione discontinua fuerit par eorumque numerorum excessu exeunte sub numero pari per medium intelligibilem inter numeros mediales multiplicetur numerus locorum et habetur quod queritur.

Exemplum quarte regule.

5.9.13.17. vel sic 3.5.7.9.

vel sic 2.4 . 6 . 8 . 10.12. vel sic 3 .7 . 11 . 15 .

\section{Quinta regula.}

Numero locorum secundum progressionem discontinuam exeunte sub numero impari per medium multiplicetur numerus locorum et habetur quod queritur.

\section{Exemplum quinte regule.}

4.6.8. vel sic 3.5.7.9.11 .13.15.

vel sic 12.14.16. velsic 3.7.11 . 15. 19.23.27. 
Sexta regula sed est de numeris arithmetica proportionaliate colleciis.

Si plures numeri ubi posterior suum immediate precedentem proportione dupla excedat insimul compareniur dupletur ultimus et a resultante subtrahitur primus et habetur quod queritur.

\section{Exemplum sexte regule.}

$12.4 .8 \cdot 16.82$. vel sic $2.4 .8 \cdot 16$.

Explicit tabula exemplarium summule super progressione continua et discontinua secundum Norefolk. 
Cod. Arund 373. fol. 1.wec. XII.

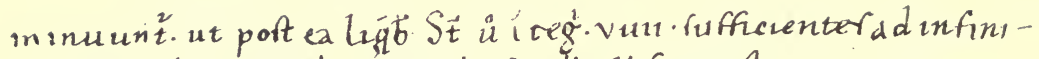
fá malteplicataone' qua noid ringtir rér fuprecta.

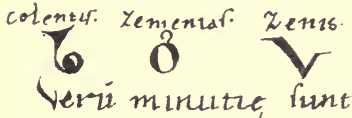
[ialcus a

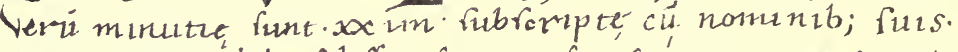
deunx dextant dodranf biffs. feptunx. femir quaux. truent quadranf.

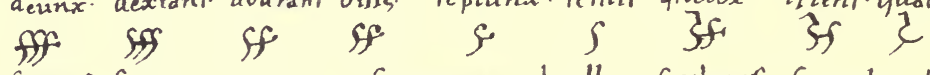
feretdnf. rexcunces uncia. Semunced. duelld ficilucur rextuld dragnid.
3
f

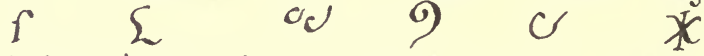

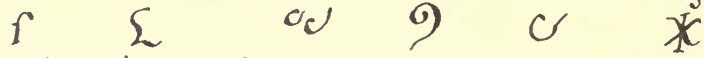

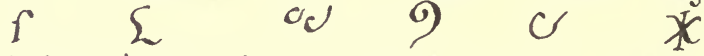

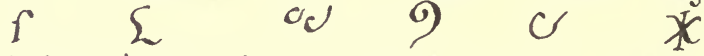

emifforela tremuffir tempulur. obuluf cerater. riliqua chalcus. 


\section{A P P E N D I X.}

\section{I.}

$A$ few Observations on the Numerical Contractions found in some manuscripts of the Treatise on Geometry by Boetius.

ThE remarks which follow have not, as far as I am aware, found a place in any prior publication: I intend them to form an appendix to the interesting chapter on the same subject presented to the literary world by $\mathbf{M}$. Chasles.

I could not have connected the following pages in the form of a continuous history, without introducing much that is already known; I have, therefore, considered it advisable to place my notes under distinct articles, without any attempt at arrangement.

1. It is very probable that the well-known passage on the Abacus, in the first book of the Geometry of Boetius, is an interpolation. For in a MS. once belonging to Mr. Ames, no such passage appears; and in another, now in the library of Trinity College, it is also wanting: again, no such contractions occur in any copy of the Treatise on 
Arithmetic* by the same author; although, in the library $\dagger$ just mentioned, there is a list of them, on a fly-leaf to a MS. of that work, in a hand-writing of the fourteenth century, which is thus headed:

Primus igin; andras; ormis; quarto subit arbas;

Quinque quinas; termas; zenis; temenias; celentis.

and over these names the contractions are written, as well as Roman numerals explaining them.

2. There are two MSS. in the Bodleian Library which merit particular attention. One, MS. Hatton. 112, possesses two distinct treatises on arithmetic on this system : the first is very extensive, but anonymous; the rubrication to the preface of the other is as follows: Incipit prefatio libri Abaci quæ junior Berhelinus edidit Parisiis, Domino suo Amulio. In both these treatises, as well as in the other MS., local position is clearly pointed out.

3. Vossius $\ddagger$ attributes them to a Grecian origin; Huet $\S$ derives them from the Hebrew; and the Bodleian MSS. refer them to Syria and Chaldea. It is scarcely necessary to observe, that there is no connection between these numerals and those among the contractions of Tyro and Seneca.

4. M. Chasles has confused the sipos and celentis, the latter of which was seldom used as a cipher. In the second Bodleian MS. we read, inscribitur et in ultimo figura 0, sipos nomine. Que licet numerum nullum significet: tum ad alia quadam utilis est. In.the

- Most of the MSS. of this work that I have examined are very old,generally prior to the thirteenth century. Only one MS. that I am acquainted with (Bib. Burn. 275.) contains Arabic numerals. It may also be remarked here, that a treatise on arithmetic in verse, by one Leopald (Bib. Arund. 339.) possesses numerals whose forms are, as far as I know, unique. But this tract will receive its due attention in a proper place.

+ R. xv. 16. There are also a few pages on arithmetic, which contain the following account of its rise among the ancients: Hanc igitur artem numerandi apud Grecos Samius Pitagoras et Aristoteles scripserunt, diffusiusque Nicomachus et Euclides; licet et alii in eadem floreunt, ut Erastosthenes et Crisippus. Apud Latinos primus Apuleius, deinde Boecius.

¥ Observationes ad Pomponiam Melam. 4to. Hag. Com. 1658, p. 64.

$\S$ Demonstratio Evangelica. Prop. iv. p. 173. E. 
Lansdown collection (842) in the British Museum, is a very beautiful MS. of the whole works of Boetius : what renders it more interesting in the present inquiry, is the contraction for the sipos without the drawing of an abacus, which curiously illustrates the difficulty of the transition from numerical operations, by means of that instrument, to local position without distinguishing boundaries.

5. The Metz MS. in the Arundel collection, referred to by Mr. Hallam, is probably an abridgment of one or more extensive treatises on the subject: the author says, quicquid ab abacistis excerpere potui compendiose collegi, componens inde mihi certas regulas, que volentibus ad hanc disciplinam attingere non inutiles. He quotes Boetius.

6. The following verses occur in a MS.* of the fourteenth century on arithmetic:

Unus adest igin; andras duo; tres reor armin;

Quatuor est arbas; et per quinque fore quinas;

Sex calcis; septem zenis; octo zenienias;

Novem celentis; per deno sume priorem.

And a list of the contractions is given on the preceding page of the same volume.

7. The fractional notation appears to be as curious as the integral, but the contractions are not quite so arbitrary, and a regular system is evidently followed up throughout. It is for the most part merely an adapta-

* Bib. Trin. Coll. Cant. inter MSS. Gal. O. 2.45. f. 33b. Chasles has given verses to the same import, but he does not mention the source whence he has obtained them. There is every reason to think that the sipos was a later improvement, and the Metz MS. contains no allusion to it. Mr. Barnwell, of the British Museum, informs me, that a short tract on celentis was once pointed out to him in a MS. volume belonging to that establishment, but no reference to it being in any of the catalogues, I have not been fortunate enough to find it. 
tion of the Roman weights to numerical computation; for instance, taking as for unity, we have-

$$
\begin{aligned}
& \frac{1}{12} \text { deunx } \\
& \frac{9}{12} \text { dodrans } \\
& \frac{7}{12} \text { septunx } \\
& \frac{5}{12} \text { quicunx } \\
& \frac{3}{12} \text { quadrans } \\
& \frac{1}{12} \text { uncia }
\end{aligned}
$$

$$
\begin{aligned}
& \frac{1}{12} \frac{0}{2} \text { dextans } \\
& \frac{8}{12} \text { bisse } \\
& \frac{6}{12} \text { semis } \\
& \frac{4}{12} \text { triens } \\
& \frac{2}{12} \text { sextans }
\end{aligned}
$$

The uncia was also divided into twelve portions, but differently-

$$
\begin{aligned}
& \frac{1}{2} \text { semiuncia } \\
& \frac{1}{4} \text { sicilius } \\
& \frac{1}{8} \text { dragma } \\
& \frac{1}{1 \frac{1}{8}} \text { tremissis } \\
& \frac{1}{48} \text { obulus } \\
& \frac{1}{96} \text { ceraces }
\end{aligned}
$$

$$
\begin{aligned}
& \frac{1}{3} \text { duella } \\
& \frac{1}{6} \text { sexcula } \\
& \frac{1}{12} \text { hemissecla } \\
& \frac{1}{24} \text { scrupulus } \\
& \frac{1}{5} \text { bissiliqua } \\
& T^{\frac{1}{44}} \text { siliqua }
\end{aligned}
$$

To these was added the ${ }_{1} \frac{1}{9} \frac{1}{2}^{\text {th }}$ part of the uncia: ut usque ad minimum extremum diatessaron et diapente symphoniarum tonorum semitonorumque intervallis distinclarum, harum fractionum denominatio conscenderet vel contenderet. Zambertus gives the contractions, qua sepissime inveniuntur in antiquis libris.* In the Metz MS. the contraction for the as is omitted. Several examples of reckoning time by this method occur in the classical writings, especially in Pliny, $t$ as also in some MSS. of the eleventh and twelfth centuries in the British Museum. Bede wrote a tract on this fractional notation, and he adds, hec ponderum vocabula, vel characteres non modo ad pecuniam mensurandam, verum ad quavis corpora, sive tempora dimetienda, conveniunt. A MS. in the Public Library (Kk. v. 32) contains an explanation in

- Euclidis Elementa ex Campano a Zamberto, fol. Par. 1516, p. 248.

† Archæologia, vol. xxvi. p. 159. Vid. Bedæ Opera. Edit. Bas. 1563, t. i., col. 101, 141, et 182. MS. Arund. Mus. Brit. 25, f. 124, et 356, f. 45. 
Saxon, which very much coincides with that given by Bede, and would appear to be taken from it.

It would be impossible, with the few materials yet brought to light, to conjecture with any great probability how far these Boeiian contractions may have influenced the introductioil, or co-operated with the Arabic system to the formation, of our present numerical notation. It appears to me highly probable that the iwo systems became united, because the middle age forms of the figure five coincide with the Boetian mark for the same numeral, and those of two others are very similar. The idea of local position, again, may have had an independent European origin; the inconveniences of the abacus on paper would have suggested it by destroying the distinguishing boundaries, and inventing an arbitrary hieroglyphic for the representation of an empty square. 
II.

\section{NOTES ON EARLY ALMANACS.*}

THE following short paper has been compiled from notes collected at various times, and without any intention of placing a dissertation on the subject before the public. I mention this merely to suggest to the reader that no connected history of almanacs has been attempted, and that it will be unfair to view what is here placed before him as any other than an attempt to abridge the labour of a successor who might wish, at some future period, to dive more deeply into the subject.

The early history of almanacs is involved in much obscurity. The Egyptians, indeed, possessed instruments answering most of the same purposes: but the log calendars are the most ancient almanacs, properly so called. Verstegan $\dagger$ derives their name from a Saxon origin, viz. al-mon-aght, or the observation of all the moons, that being the purpose for which they were originally made: an eastern origin would appear to me to be more probable. They are doubtless of high antiquity, and, if we can be guided by the errors of the more modern ones in their

* This has been printed in the "Companion to the British Almanac" for 1839 ; to the kindness of Mr. Knight, the publisher of that useful periodical, I an indebted for power to reprint it here.

$\dagger$ Restitution of decayed intelligence, p. 64 . 
ecclesiastical computation, we might refer them to the second or third century.* Gruter has delineated one at Rome, and which is said to have been used by the Goths and Vandals : this was cut in elm, though most are in box, and some few in fir, brass, horn, \&c. Each of these calendars contains four sides, for the four quarters of the year, and gives the golden numbers, epacts, dominical letter, \&c. The numerical notation is imperfect but curious; dots are put for the first four digits, a mark similar to the Roman numeral V, for five; this mark, and additional dots for the next four, and the algebraical sign + for ten. Specimens of these logs may be seen in the British Museum †; and, as they are not uncommon, it is unnecessary to enter into further detail.

Before I commence with written almanacs, it will be necessary to remark the distinction between astronomical and ecclesiastical calendars, the first of which contain astronomical computations, and the other lists of saints' days, and other matters relative to the church; sometimes, indeed, both are found united, although the latter claim a higher antiquity, being prefixed to most ancient Latin manuscripts of the Scriptures.

The folding calendars were, perhaps, the most ancient forms of them, and merit particular attention. Several of these are in the British Museum, $\ddagger$ and at Oxford; one of them was written in the year 1430, and is in English; but the writer confesses his inability to find suitable expressions

- MS. Harl., Mus. Brit., 5958.

$\uparrow$ MSS. Harl., 197, 198. The last of these is a modern one used in Derbyshire or Staffordshire, and cut, probably, in the latter part of the $17 \mathrm{th}$ century: the other one is much earlier, though perhaps not of very high antiquity. Others may be seen in the Ashmolean Museum, and in St. John's College, Cambridge. I refer to Dr. Plott's History of Staffordshire for a very good description of them. (See also Brady's Clavis Calendaria.)

$\ddagger$ Cotton Rolls, viii. 26 ; MSS. Harl. 937, 3812, 5311; MSS. Sloan. 996, 2250 ; which last is the calendar of John Somers, afterwards mentioned. There is also one in the Ashmolean collection at Oxford in singularly fine preservation. 
for the technical terms which were derived for the most part from Arabic, for defawie of terms convenyent in our moder langage. In the Pepysian library at Cambridge there is one printed by Wynkin de Worde, in octo-decimo, which, in its original form, folds up from a small folio sheet of vellum; it bears the date of 1523.*

The standard almanacs emanated from Oxford, the seat of British science throughout the middle ages: in fact, before Newton's time, Cambridge was a blank, and the only scientific names that cheer the pages of the history of its early literature are Holbroke of St. Peter's College, Buckley of King's, and Dee of St. John's : the first known by his astronomical tables, the second by a plagiarism of a method of extracting the roots of fractions from Robert Record, and the third a memorable instance of one of the greatest men of his time uniting the pure truths of science with the grossest absurdities. All three were astrologers, $\dagger$ owing, perhaps, more to the place of their education than to the individuals themselves.

There has been some dispute relative to the authenticity of Roger Bacon's calendar, of which there is a MS. in the British Museum : the following is an exact transcript of the commencement :-

"Kalendarium sequens extractum est a tabulis tholetanis . anno domini. 1292. factus ad meridiem civitatis tholeti que in Hispania scita est cujus meridianus non multum distat a meridiano medii puncti Hibernie in quo. 3. continentur." f. 2 .

If we retain factus, it cannot be translated, but, fortunately, the other MS. at Oxford has factum, and this must evidently be the true reading. Professor Peacock

- Hartshorne's 'Book Rarities of Cambridge.'

$\dagger$ Holbroke is admitted by all to have been an astrologer. Buckley wrote a treatise which involves the principles (MS. Bib. Reg. $12 \mathrm{~A} . \mathrm{xxv}$.); and with respect to Dr. Dee, no doubt can arise. 
writes factis, but there is not, as far as I know, any MS. auihoriiy for it. With respect to the author of it, the Bodleian MS., in a coeval rubric, states the calendar to have been written à fratre Rogero Bacon; while the Coiton MS., not having any original title, is ascribed to Roger Bacon, in a hand of the 17th century: both of the MSS. belong to the 14th century. In the Harleian collection (No. 941) is a MS. on the length of the days throughout the year, stated to have been made at Oxynforde be the new kalendere and proved in all the university: this new kalendere may possibly refer to Roger Bacon's; but there are not sufficient data to enable us to attain an approach to certainty.

'The calendar of John Somers, of Oxford, written in 1380 , was one of the most popular of the time: there is generally appended to it, Tabula docens algorismum legere, cujus utilitas est in brevi satis spatio numerum magnum comprehendere. Et quia numeri in kalendario positi vix excedunt sexaginta, ultra illam summam non est protensa.* Several English translations of this tract are among the Ashmolean MSS.

We have likewise in MS. Almanach Profacii Judei, which is very ancient. Walter de Elvendene wrote a calendar in 1327, $\uparrow$ and Nicholas de Lynna published another in 1386. $\neq$ Sometimes these calendars are found in rolls.

In the library at Lambeth Palace is a very curious calendar in the English language, written in 1460; at the end is a table of eclipses from 1460 to 1481 ; but a very perfect volvelle is most worthy of notice, because those instruments are generally found imperfect. In the Cottonian collection is another English calendar, written about

- MS. Bib. Cott. Mus. Brit. Vespas. E. vii. f. 4.

$\dagger$ MS. Sloan. Mus. Brit. 286. $\quad$ \$ MS. Ashm. Oxon. 5. 
1450 , but so much damaged by the fire that the nature of it cannot be seen. In Trinity College, Cambridge, there is a MS., said to have been composed in 1347, and entitled, An Almanak, translated in perpetuite, out of Arabike into Latin; and in the same library I find The Effemerides of John of Mounte Riol, a German Prince of Astronomyers. Professor Leslie mentions a very beautiful calendar in the library of the university of Edinburgh, with the date of 1482: he does not appear to be aware that they were common in MS. libraries, and he greatly overrates its value.

There was printed at Hackney, in 1812, a small octavo volume, containing an account of an English almanac for the year 1386 : it contains a very large portion of astronomical and medical matter, but appears to be of little interest, save that it is the earliest one in English I have ever heard of. The contents of this calendar are as follow :-

1. The houses of the planets and their properties.

2. The exposition of the signs.

3. Chronicle of events from the birth of Cain.

In 1325 there was a grete hungur in England; in 1333 a great tempest; in 1349 the first, in 1361 the second, and in 1369 the third pestilence. It is curious to remark the clumsy method of expressing numbers consisting of more than two figures: for instance, we have $52 \mathrm{mcc} 20$ put for 52,220. This shows that the Arabic notation was even then but imperfectly understood among the common people.

4. To find the prime numbers.

5. Short notes on medicine.

6. On blood-letting.

7. A description of the table of the signs, and moveable feasts.

8. Quantitates diei artificialis. 
The extracts from this calendar are wretchedly transcribed, and evidently by one who was totally unacquainted with MSS.

The clock or albion of Richard de Walingford, of St. Alban's, answered the purpose of a calendar. * This clock made, says Bale, who appears to have seen it, magno labore, majore sumptu, arte vero maxima, was considered the greatest curiosity of its time. In his account of it, which still remains in manuscript, we have the following definitions:-Albion est geometricum instrumentum : almanac autem arismetricum. Peter Lightfoot's celebrated astronomical clock at Glastonbury may have been something of the same sort.

Peter de Dacia, about 1300, published a calendar, of which there is a very early MS. in the Savilian library at Oxford: the condiciones planetarum are thus stated-

Jupiter atque Venus boni, Saturnusque malignus;

Sol et Mercurius cum Luna sunt mediocres.

The homo signorum, so common in later calendars, probably originated with him.

The earliest almanac printed in England was the Sheapeheard's Kalender, translated from the French, and printed by Richard Pynson, in 1497. It contains a vast portion of extraneous matter. The following verses on the planets will, at the same time, give a good idea of the nature

- In one almanac of the commencement of the 17th century (MS. Harl. 5937. Bagford Collect., s. 139) is a very singular method for finding the hour of the day, if in the country and without any watch. I refer to it merely out of charity to those right-hearted enthusiastic antiquaries who do not stick at trifles in pursuing researches that can in any way illustrate the customs of our ancestors in the good old times. To those who only value the researches of antiquaries in proportion as they are likely to furnish some evident tangible utility, I would willingly spare their time in recurring to a method which, though it might excite their ridicule, could never, from its nature, be brought into practice in the present age. 
of the astrological information in this and other calendars of the period:-

" Some hot, some colde, some moyst, some dry, If three be good, foure be worse at the most.

Saturne is hyest and coldest, being full old, And Mars, with his bluddy swerde, ever ready to kyll ; Jupiter very good, and Venus maketh lovers glad, Sol and Luna is half good and half ill, Mercury is good and will verily And hereafter shalt thou know; Whiche of the seven most worthy be, And who reigneth hye, and who a lowe;

Of every planets propertie, Which is the best among them all, That causeth welth, sorrowe, or sinne, Tarry and heare sone thou shalt, Speake softe, for now I beginne."

Afterwards follow some prognostications of the weather. The following method to knowe what wether shall be all the yere after the chaunge of every moone by the prime dayes, is taken from a MS. in Lambeth Palace:-

"Sondaye pryme, drye wether. Mondaye pryme, moyst wether. Teusdaye pryme, cold and wynde. Wenesdaye pryme, mervelous. Thursdaye pryme, sonne and clere. Frydaye pryme, fayre and fowle. Saturdaye pryme, rayne."

Prognostications of the weather were early matters of reproach-.

"Astronomyers also aren at ere whittes ende,

Of that was calculed of the clymat the contrye thei fyndeth.

And in Heber's library was a little tract of three leaves, entitled 'A Mery Prognostication'-

"For the yere of Chryste's incarnacyon, A thousande fyve hundreth fortye and foure.

This to prognosticate I may be bolde,

That whan the new yere is come, gone is the olde." 
Henry VI1I. issued a proclamation against such false prognosications as this tract was intended to ridicule, but siill no printer ventured to put his name to it. Not long after to believe them was a crime; "as for astrologicall and other like vaine predictions or abodes," says Thomas Lydiat, "I thanke God I was never addicted to then." *

Johannes de Monte-Regio, in 1472, composed the earliest European almanac that issued from the press; and, before the end of that century, they became com. mon on the Continent. In England they were not in general use until the middle of the sixteenth century. Most of the best mathematicians of the time were emploved in constructing them; but, before the end of the following century, almanac-makers began to form a distinct body, and, thongh they often styled themselves "studentes in the artes mathematicall," very few of them were at all celebrated in the pure sciences.

It may not be wholly irrelevant here to make some few observations on the memory-rhymes found in some almanacs of the present day, and which date their origin to a much earlier period. The well-known lines, used by many for recalling to their recollection the number of days in each month, I find in Winter's Cambridge Almanac for 1635, under the following slightly-varied form-

"Aprill, June, and September, Thirty daies have as November;

Ech month else doth never vary From thirty-one, save February;

Wich twenty-eight doth still confine, Save on Leap-yeare, then twenty-nine."

And the nursery-rhymes, commencing "Multiplication is my vexation," were certainly made before $1570 . \dagger$

- MS. Bodl. 662.

+ Professor Davies's Key to Hutton's Mathematics, p. 17. 
The early history of ecclesiastical computation is intimately connected with that of calendars. Dionysius Exiguus was one of the first who wrote on the subject: after him, Bede, Gerlandus, Alexander de Villa Dei, and Johannes de Sacro-Bosco, were the most celebrated. The Massa Compoti of Alexander de Villa Dei, so common in MS., is perhaps the most singular tract on the subject that has come down to us: his reason for the title of the book is exceedingly curious:-Sicut de multis laminis aris in conflatorio massa una efficitur, ideo librum istum vocari volui massam compoti.

I cannot conclude withont mentioning the 'Almanac and Prognostication' of Leonard Digges, which was so often reprinted in the latter half of the sixteenth century: it is filled with the most extravagant astrological absurdities, and a table of weather predictions. With respect to the latter, however, I have had the curiosity to test its accuracy for some months in comparison with our two celebrated weather almanacs, and, on the average, have found it to be quite as " neare the marke." as either of them.

THE END. 


\section{CORRECTIONS AND ADDITIONS.}

P. 2, 1. 31.-For idem, read eandem.

P. 3, 1. 13.-For muneri, read numeri.

P. 6, 1. 20.-For nonenarii, read novenarii, and in other places.

P. 7, 1. 18.-For supponatur, read supraponatur.

P. 11, 1. 25, 29.-For vide, read vid.

P. 12, 1. 22.-For quinam, read quando.

P. 15, 1. 21.-For perdictis, read prædictis.

P. 19, 1. 11.-For quidenarius, read quindenarius.

P. 19, 1. 25.-For perambulum, read præambulum.

P. 26, 1. 15.-Sibi ; so in the manuscript, but evidently sub.

P. 29, 1. 4.-For 14, read 15 .

P. $30,1.2,6,7$; P. $31,1.1,13$.- It will be readily seen that $y$ is inserted in these places for $t h$, the Saxon character having been mistaken by the printer.

P. 51, 1. 17.-For ince, read vice. I may mention here, that it was pointed out to me by an eminent classical scholar, that a portion of this preface is plagiarised from Cicero.

P. 54, 1. 18.-Cædere; so in the manuscript, but evidently cedere.

P. 55.-This table has been previously noticed, and in part printed by J. W. Lubbock, Esq., in Phil. Trans. I was not aware of this when my own-transcript was passing through the press, or it would have been acknowledged in the proper place.

P. 55, Second table, 1. 1.-For 10, read 0 .

P. 56. I am not quite certain that the poetry quoted at the bottom of the page refers to Euclid the Geometer.

P. 57, 1. 17.-For Bathoniensum, read Bathoniensem.

P. 73, 1. 21.-For nihil, read in his.

P. 73, 1. 22.-For potuit, read patuit.

P. 84, 1. 12.-For descriptos, read desuper.

P. 85, 1. 16.-For principem, read patrem. 
NOTE.

The foregoing volume was published at three several times: the first part (pp. 1-48) appeared on the 1st of June, 1838 ; the second (pp. 49-96) on the 1st of October, 1838 ; and the remainder on the 1st of June, 1839. Some parts of the volume were printed without the Editor's final corrections, which will account for a few oversights; and it ought to be particularly remarked, that in no instance has the regular correction of the errors in the MSS. from which these tracts are printed been attempted. 


\section{BY THE SAME AUTHOR.}

I.-A Brief Account of the Life, Writings, and Inventions of Sir Samuel Morland, Master of Mechanics to Charles the Second. 8vo. Camb. 1838.

II.-Two Essays : I. An Inquiry into the Nature of the Numerical Contractions found in a passage on the Abacus in some Manuscripts of the Geometry of Boetius. II. Notes on Early Calendars. 8vo. Lond. 1839.

III.-The Travels of Sir John Maundevile, Knt. to the Holy Land, and other parts of Asia, in the 14th century. Reprinted from the edition of $\mathbf{1 7 2 5}$. With an Introduction, additional Notes, and Glossary. 8vo. Lond. 1839. 
(3) 



\section{UNIVERSITY OF CALIFORNIA LIBRARY BERKELEY}

Return to desk from which borrowed.

This book is DUE on the last date stamped below.

IINov'49HJ

11Dec'620TL

REC'D LD

DEC 51962

AUG 061991

REG CIR.AUG 6

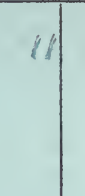

LD 21-100m-9,'48(B399s16) 476

NOV 12, 1977

REC. CIR. MAN 29 '91

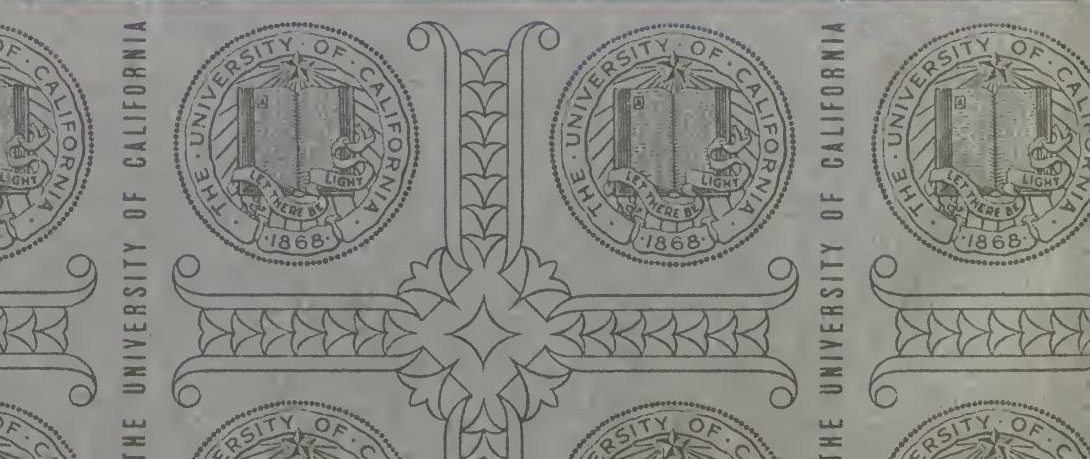




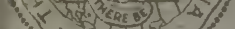

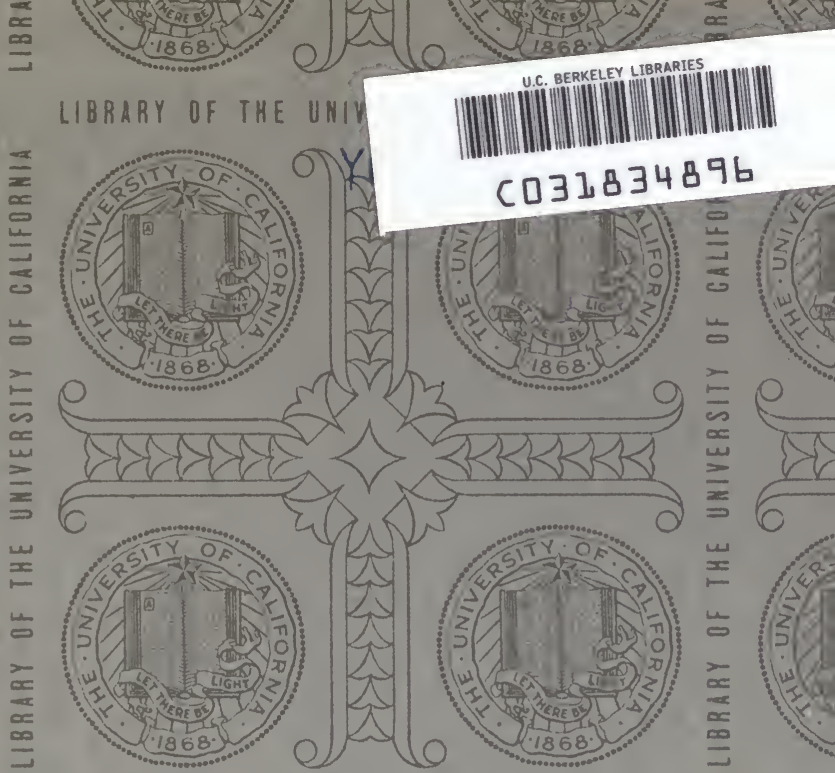

IY OF GALIFORNIK

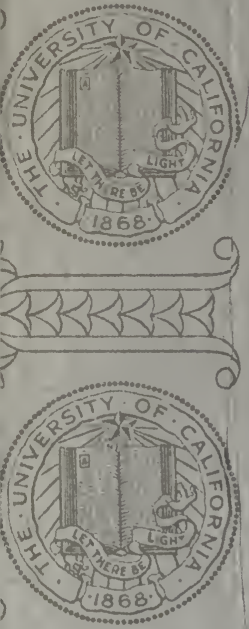

Y OF CALIFORNIA

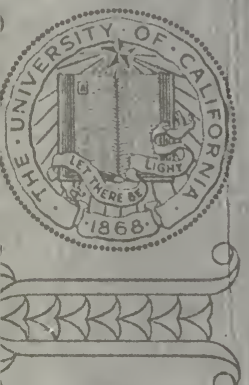

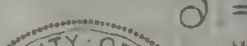

LIBRARY OF THE UNIVERSITY OF CALIFORNIA

LIBRA
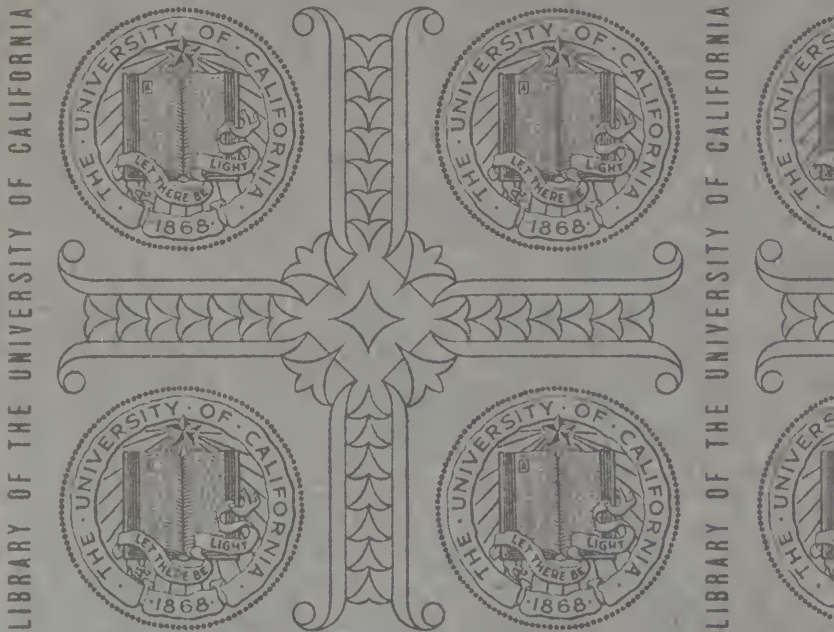

LIBRA

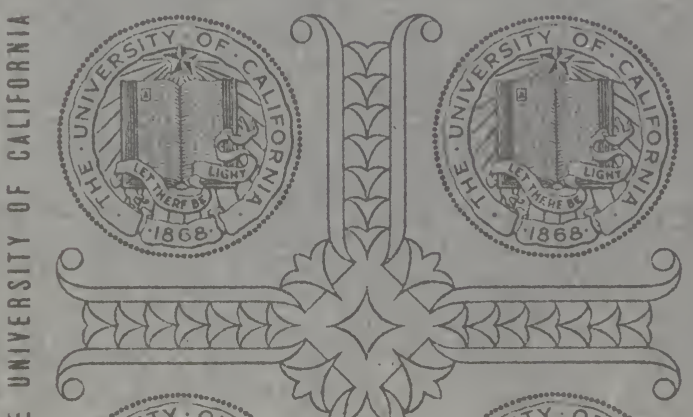

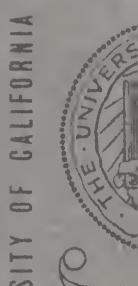


